\title{
Effects of Different Regional Climate Model Resolution and Forcing Scales on Projected Hydrologic Changes
}

Pablo A. Mendoza ${ }^{1,2,3,}$, Naoki Mizukami ${ }^{3}$, Kyoko Ikeda ${ }^{3}$, Martyn P. Clark ${ }^{3}$, Ethan D. Gutmann ${ }^{3}$, Jeffrey R. Arnold ${ }^{4}$, Levi D. Brekke ${ }^{5}$ and Balaji Rajagopalan ${ }^{1,2}$

${ }^{1}$ Department of Civil, Environmental, and Architectural Engineering, University of Colorado at Boulder, Boulder, Colorado, USA

${ }^{2}$ Cooperative Institute for Research in Environmental Sciences, University of Colorado at Boulder, Boulder, Colorado, USA

${ }^{3}$ Hydrometeorological Applications Program, National Center for Atmospheric Research, Boulder, Colorado, USA

${ }^{4}$ Climate Preparedness and Resilience Programs, U.S. Army Corps of Engineers, Seattle, USA

${ }^{5}$ Bureau of Reclamation, Denver, USA

Running head: Effects of RCM resolution on hydrologic changes

Keywords: climate change; regional climate model; spatial aggregation; horizontal resolution; hydrologic model structure

Manuscript submitted to Journal of Hydrology

${ }^{*}$ Corresponding author. Email address: pmendoza@ucar.edu (Pablo A. Mendoza) 


\section{Abstract}

We examine the effects of regional climate model (RCM) horizontal resolution and forcing scaling (i.e., spatial aggregation of meteorological datasets) on the portrayal of climate change impacts. Specifically, we assess how the above decisions affect: (i) historical simulation of signature measures of hydrologic behavior, and (ii) projected changes in terms of annual water balance and hydrologic signature measures. To this end, we conduct our study in three catchments located in the headwaters of the Colorado River basin. Meteorological forcings for current and a future climate projection are obtained at three spatial resolutions (4-, 12- and 36$\mathrm{km}$ ) from dynamical downscaling with the Weather Research and Forecasting (WRF) regional climate model, and hydrologic changes are computed using four different hydrologic model structures. These projected changes are compared to those obtained from running hydrologic simulations with current and future 4-km WRF climate outputs re-scaled to $12-$ and 36-km.

The results show that the horizontal resolution of WRF simulations heavily affects basinaveraged precipitation amounts, propagating into large differences in simulated signature measures across model structures. The implications of re-scaled forcing datasets on historical performance were primarily observed on simulated runoff seasonality. We also found that the effects of WRF grid resolution on projected changes in mean annual runoff and evapotranspiration may be larger than the effects of hydrologic model choice, which surpasses the effects from re-scaled forcings. Scaling effects on projected variations in hydrologic signature measures were found to be generally smaller than those coming from WRF resolution; however, forcing aggregation in many cases reversed the direction of projected changes in hydrologic behavior. 


\section{Introduction}

Although global climate models (GCMs) are widely used for generating information on future climate scenarios, their native grid size $(\sim 100-200 \mathrm{~km}$ on a side) is a serious limitation for characterizing climate projections at the basin scale, where features such as elevation and aspect become relevant. To reconcile differences between coarse resolution GCM outputs and regional or local scale climate processes, Regional Climate Models (RCMs) are run with lateral boundary conditions from GCMs to force fine-scale climate simulations, a process typically referred to as dynamical downscaling (Xu 1999; Fowler et al. 2007). Teutschbein and Seibert (2010) presented a detailed review of approaches that make use of RCMs for quantifying climate change impacts on hydrologic processes, and a plethora of additional example applications can be found in the literature (e.g., Wood et al. 2004; Steele-Dunne et al. 2008; Suklitsch et al. 2008; Kay et al. 2009; Prudhomme and Davies 2009; Gao et al. 2011; Vicuña et al. 2011; Majone et al. 2012; Wi et al. 2012; Lauer et al. 2013; Velázquez et al. 2013).

However, a key aspect rarely explored is the choice of RCM horizontal resolution, which determines how precipitation - in particular snowfall - and other hydrologic variables are represented in highly heterogeneous regions (Rasmussen et al. 2011). For example, Kleinn et al. (2005) compared hydrologic model simulations forced with 14-km and 56-km RCM outputs in the Rhine basin in Central Europe, finding that although the finer resolution provided more realistic precipitation fields, improvements in streamflow simulation skill were small. Contrarily, Dankers et al. (2007) showed that 12-km simulations conducted with the HIRHAM RCM provided a better representation of orographic patterns and extreme precipitation events in the Upper Danube basin in Central Europe, and better simulations of hydrologic extreme events at 
the sub-basin scale in comparison to coarser (50-km) RCM outputs. Graham et al. (2007) concluded that a $25-\mathrm{km}$ resolution provided more systematic and less spatially variable biases in RCM precipitation and temperature fields when compared to 50-km resolution. Van Roosmalen et al. (2010) evaluated the implications of choosing different RCM resolutions (12-, 25- and 50$\mathrm{km}$ ) on delta change factors (e.g., additive perturbation for temperature, multiplier for precipitation) - from a control and future climate scenario - computed at a monthly basis for Denmark, finding that the added value of increasing resolution was almost negligible. A set of studies conducted in the Colorado Headwaters Region (Ikeda et al., 2010; Rasmussen et al., 2011, 2014) explored the effects of horizontal resolution using the Weather Research and Forecasting (WRF) regional climate model (Skamarock et al. 2008). Specifically, they showed that the use of horizontal resolution of $6 \mathrm{~km}$ or less in RCMs allowed accurate estimations of vertical motions driven by topography without the need to include a convective parameterization scheme, improving the representation of seasonal snowfall and snowpack. Along these lines, Prein et al. (2013) compared the effects of different horizontal resolutions (4-, 12- and 36-km) on daily heavy precipitation events simulated by WRF over the same domain, finding that only the 4-km simulation was able to reproduce heavy summertime events, and that both 4-km and 12-km outputs were comparable and superior to the $36-\mathrm{km}$ simulation when looking at winter events. More recently, Olsson et al. (2015) obtained similar findings - i.e., better simulation of summer extremes and summer wet spells - when moving from 50-km to 6-km horizontal grids.

The choice of the RCM resolution is typically determined by climate modelers to optimize some constraints including available computer (i.e., time to compute the solution) and the need to represent selected important atmospheric processes as explicitly as possible, but the domains of these solutions are nearly always rectilinear for the Eulerian grid. However, hydrologic 
modelers choose any shaped spatial element named Hydrologic Response Unit (HRU) at which the hydrologic model is run. The HRUs can be the entire catchment, a grid box, or hydrologically similar areas (e.g., similar soil-vegetation areas) and those are at different scale than RCM resolution. Accordingly, scaling or spatial aggregation of RCM outputs is nearly always required to obtain HRU averaged meteorological forcing. Several studies have examined the hydrologic implications of spatially aggregating meteorological fields from finer scales (e.g., Finnerty et al. 1997; Koren et al. 1999; Bell and Moore 2000; Arnaud et al. 2002; Liang et al. 2004; Shrestha et al. 2006, 2007; Tramblay et al. 2011; Rasmussen et al. 2012), showing mixed conclusions. Lobligeois et al. (2014) conducted a detailed review of previous efforts, and analyzed the benefits of using high-resolution rainfall fields for flood simulation, including a large sample of flood events (3620) in a large number of catchments (181); although they concluded that these effects are "scale-dependent and event-specific-dependent", they also found that regions with high spatial rainfall variability obtained the greatest benefits from highresolution precipitation inputs. Importantly, none of the above studies assessed the sensitivity of hydrologic changes to the spatial scale at which historical and future climate datasets are used.

Given the evidence showing that RCM resolution affects climate outputs, a natural question that arises is how the effects of RCM horizontal resolution on hydrologic portrayals of climate change compare to those of scaled RCM at the same horizontal resolution. This paper examines how the grid spacing adopted in a RCM for dynamical downscaling affects hydrologic change estimates. In particular, we aim to characterize these effects on: (i) historical simulation of signature measures of hydrologic behavior (e.g., runoff ratio, seasonality, log-term baseflow), and (ii) projected hydrologic change in terms of annual water balance and hydrologic signature measures. Further, we compare the implications of choosing different horizontal grid sizes to 
those associated with spatial aggregation of high resolution RCM output. Given the increasing awareness of the importance of hydrologic model structural uncertainty to climate change impact studies (e.g., Boorman and Sefton 1997; Jones et al. 2006; Jiang et al. 2007; Kay et al. 2009; Ludwig et al. 2009; Bae et al. 2011; Bastola et al. 2011; Najafi et al. 2011; Poulin et al. 2011; Miller et al. 2012; Vano et al. 2012; Surfleet et al. 2012; Addor et al. 2014; Mendoza et al. 2015, 2016; Mizukami et al. 2016), we include four different hydrologic/land surface models for two reasons: to examine the robustness of $\mathrm{RCM}$ resolution and forcing aggregation effects, and to obtain insights on the relative importance of forcing-related decisions versus hydrologic model choice.

The remainder of this paper is organized as follows. Section 2 provides a description of the study domain. Section 3 describes the meteorological forcing data, hydrologic models and the experimental design adopted in this study. Section 4 illustrates how the choice of RCM horizontal resolution and forcing aggregation affect hydrologic portrayals - obtained from different hydrologic models - under historical and modified climatic conditions. Finally, section 5 summarizes our main findings.

\section{Study Area}

The Colorado River basin $(\mathrm{CRB})$ is one of the major water sources for consumption, irrigation and hydropower in the western United States, draining parts of seven states and Mexico, and covering the needs of more than 30 million people. Given its strategic relevance, several studies have been conducted to quantify the potential effects of changes in precipitation and temperature on the hydrology of this area (e.g., Milly et al. 2005; Christensen and Lettenmaier 2007; Hoerling and Eischeid 2007; Ray et al. 2008; Rasmussen et al. 2011, 2014; 
Miller et al. 2011, 2012; Bureau of Reclamation 2012; Vano et al. 2012; Vano and Lettenmaier 2014). Much of the water for this region comes from the high-elevation area - the Colorado Headwaters - that act as a natural reservoir during the winter, storing precipitation as snowpack. Hence, we select three basins in the Colorado Headwaters with outlets at streamflow stations managed by the United States Geological Survey (USGS) - Yampa River at Steamboat Springs, East River at Almont and Animas River at Durango - whose location and elevation ranges are shown in Figure 1.

Table 1 summarizes the main hydroclimatic characteristics of the three basins for which historical data are available, over an 8-year period (Oct/2000 - Sep/2008). Mean basin precipitation ranges between $700 \mathrm{~mm} /$ year to $900 \mathrm{~mm} / \mathrm{year}$, while mean basin elevation is above 2500 m.a.s.l. Among these basins, the East River at Almont has the largest runoff ratio (0.42), and the Yampa at Steamboat Springs has the lowest runoff ratio (0.32, with the lowest runoff and precipitation amounts). The land surface of the Yampa and Animas River basins is predominantly covered by deciduous forests (26\% at Yampa and $23 \%$ at Animas) and evergreen forests (37\% at Yampa and $39 \%$ at Animas), while the land surface of the East River basin is mainly covered by evergreen forests $(29 \%)$ and grassland/herbaceous (26\%).

\section{Data and methods}

\subsection{Climate datasets}

We use dynamically downscaled climate datasets obtained with the WRF model to force hydrologic simulations and compute hydrologic changes due to a climate perturbation. These datasets consist of historical (control run, CTRL) and pseudo global warming (PGW) outputs at 
three different horizontal resolutions (4-, 12- and 36-km). These WRF simulations are fully described in Rasmussen et al. (2014), but briefly reviewed below. The initial and 3-hourly lateral boundary conditions were taken from the North American Regional Reanalysis (NARR; Mesinger et al. 2006) coarse resolution dataset $(\sim 32 \mathrm{~km})$. The model physics options used in that study included the Noah Land Surface Model (Noah-LSM) version 3.2 with upgraded snow physics (Chen and Dudhia, 2001; Barlage et al., 2010), the Thompson mixed-phase cloud microphysics scheme (Thompson et al. 2008), the Yonsei University planetary boundary layer (Hong et al. 2006) and the Community Atmosphere Model's (CAM) longwave and shortwave radiation schemes (Collins et al. 2006). Because the use of a horizontal resolution of 6-km or less is able to accurately estimate vertical motions driven by topography (Ikeda et al. 2010; Rasmussen et al. 2011), a convective parameterization was included for the 12- and 36-km simulations - using the Betts-Miller-Janjić scheme (Janjić 1994)- but not for the 4-km simulation (Rasmussen et al. 2014).

The PGW approach (Schär et al., 1996; Hara et al., 2008; Kawase et al., 2009; Rasmussen et al., 2011) consists of adding monthly mean climate perturbations to the initial and 3-hourly boundary conditions taken from NARR at each WRF vertical level. The climate perturbation was obtained from the Community Climate System Model Version 3 (CCSM3) runs performed by the National Center for Atmospheric Research's (NCAR) Climate and Global Dynamics Division (Collins et al. 2006) under the A1B scenario (Nakicenovic et al. 2000; Meehl et al. 2007). This perturbation is generated by subtracting the current 10-yr (1995-2005) monthly climatology from a future 10-yr (2045-2055) monthly climatology.

Meteorological data from WRF simulations is available for all horizontal resolutions at hourly time steps, for both historical and modified climatic conditions. The $12-\mathrm{km}$ and $36-\mathrm{km}$ 
grids are perfectly aligned to each other, but not with the high-resolution 4-km grid. The output variables and temporal discretization used depend on specific hydrologic model requirements (Table 2). To compare the effects of WRF horizontal resolution - referred as experiment 1 - with those from re-scaling high-resolution outputs, we create two additional forcing datasets by regridding WRF outputs obtained at 4-km to the 12- and 36-km grid cells used by Rasmussen et al. (2014) - referred as experiment 2. This is done in two steps: (1) identification of all the 4-km grid points contained in WRF grid cells at 12- and 36-km resolutions, and (2) computation of the new forcing data from the simple average of the 4-km points contained in the 12- and 36-km grid cells.

Figure 2 includes basin-averaged monthly precipitation values computed from: (a) WRF outputs obtained by Rasmussen et al. (2014) with three different horizontal resolutions (4-, 12and 36-km), and (b) 4-km WRF outputs, re-scaled to 12- and 36-km. These results correspond to the period October/2002 - September/2008, for current (CTRL, dashed lines) and future (PGW, solid lines) climate scenarios. As a reference, observed basin-averaged monthly precipitation values, also displayed with black symbols in Figure 2, were obtained by applying the Thiessen interpolation method (Thiessen 1911) on SNOTEL observations, including 8, 4 and 11 stations for the Yampa, East and Animas River basins, respectively. The results show that a closer match is achieved using high-resolution (i.e. 4-km) WRF outputs compared to 12- and 36-km, especially at the East and Animas River basins. Although 4-km WRF underestimates basinaveraged precipitation at Yampa, especially during late winter and spring, additional analyses (not shown) suggested that a single station - located at the northeastern edge of the basin recorded much greater precipitation amounts than the others, enhancing the mismatch between observed and simulated precipitation. 
Figure 2a shows that WRF horizontal resolution affects precipitation amounts considerably. Indeed, 4-km WRF-CTRL simulations generate basin-averaged annual precipitation amounts of $735 \mathrm{~mm}, 824 \mathrm{~mm}$ and $937 \mathrm{~mm}$ in Yampa, East at Animas River basins, respectively, while the $12-\mathrm{km}(36-\mathrm{km})$ WRF-CTRL simulation produces $473 \mathrm{~mm}(371 \mathrm{~mm})$ at Yampa, $596 \mathrm{~mm}(580 \mathrm{~mm})$ at East, and $650 \mathrm{~mm}(611 \mathrm{~mm})$ at the Animas River basin. These relative differences are augmented over summer (June-September), when the 4-km WRF-CTRL outputs are $168 \mathrm{~mm}, 205 \mathrm{~mm}$ and $195 \mathrm{~mm}$ for Yampa, East and Animas, respectively, while 12$\mathrm{km}(36-\mathrm{km})$ outputs are $68 \mathrm{~mm}(39 \mathrm{~mm})$ at Yampa, $95 \mathrm{~mm}(77 \mathrm{~mm})$ at East, and $111 \mathrm{~mm}(80$ $\mathrm{mm})$ at Animas. Moreover, PGW simulations project an increase in precipitation over fall/winter and a decrease during summer months at all basins, regardless of the horizontal resolution adopted in WRF. By contrast, scaling effects (Figure 2b) on monthly precipitation amounts are minor compared to those coming from WRF resolution, with 12-km (36-km) annual totals of 715 $\mathrm{mm}(698 \mathrm{~mm})$ at Yampa, $808 \mathrm{~mm}(759 \mathrm{~mm})$ at East and $934 \mathrm{~mm}(960 \mathrm{~mm})$ at the Animas River basin. Datasets spatially aggregated at $12-\mathrm{km}(36-\mathrm{km})$ provide accumulated October-March differences of $-14 \mathrm{~mm}(-25 \mathrm{~mm})$ at Yampa, and $-17 \mathrm{~mm}(-61 \mathrm{~mm})$ at East with respect to the 4km WRF-CTRL simulation, and the 36-km aggregated dataset generated a $+10 \mathrm{~mm}$ FebruaryApril precipitation difference at Animas when compared to the same benchmark.

Figure 3 displays basin-averaged monthly temperatures computed for experiments 1 (Figure 3a) and 2 (Figure 3b). The 4-km WRF historical simulation provided annual mean temperatures of $2.1^{\circ} \mathrm{C}$ for Yampa, $-0.5^{\circ} \mathrm{C}$ for East and $1.2^{\circ} \mathrm{C}$ for Animas, while the 12-km (36$\mathrm{km})$ WRF run resulted in $1.8^{\circ} \mathrm{C}\left(1.5^{\circ} \mathrm{C}\right)$ at Yampa, $-1.1^{\circ} \mathrm{C}\left(-0.4^{\circ} \mathrm{C}\right)$ at East and $0.5^{\circ} \mathrm{C}\left(0.7^{\circ} \mathrm{C}\right)$ at Animas These differences can be mostly explained by discrepancies over December-February (DJF). Similar relative differences (i.e. higher DJF temperatures) between the 4-km WRF 
simulation and the $12-\mathrm{km} / 36-\mathrm{km}$ runs were found under the PGW climate scenario, with annual increases (i.e. future - current) in basin-averaged mean annual temperature ranging from $+2.3^{\circ} \mathrm{C}$ (Animas River basin) to $+2.5^{\circ} \mathrm{C}$ (Yampa River basin). On the other hand, Figure $3 \mathrm{~b}$ shows that scaling effects on monthly temperatures were relatively smaller, with mean annual temperatures of $2.2^{\circ} \mathrm{C}\left(2.1^{\circ} \mathrm{C}\right)$ for Yampa, $-0.5^{\circ} \mathrm{C}\left(0.1^{\circ} \mathrm{C}\right)$ for East and $1.1^{\circ} \mathrm{C}\left(0.8^{\circ} \mathrm{C}\right)$ for Animas from the re-scaled 12-km $(36-\mathrm{km})$ dataset. Moreover, the two coarse resolution datasets provided almost identical projected changes in mean annual temperature than the original 4-km WRF simulation: $+2.4^{\circ} \mathrm{C}$ in the Yampa and East River basins, and $+2.3^{\circ} \mathrm{C}$ in the Animas River basin. However, there are still differences in basin-averaged monthly temperature values among the three datasets in Experiment 2, which arise from daily temperature discrepancies and are so small that they are not distinguishable at the scale of Figure 3.

\subsection{Hydrologic/land surface models}

To explore the interplay between WRF horizontal resolutions and the choice of hydrologic model structure, we include four hydrologic/land surface models: the US Geological Survey's Precipitation Runoff Modeling System (PRMS; Leavesley et al., 1983; Leavesley and Stannard, 1995), the Variable Infiltration Capacity model (VIC; Wood et al., 1992; Liang et al., 1994, 1996) the Noah Land Surface Model (Noah-LSM; Ek 2003; Mitchell et al. 2004), and the Noah Land Surface Model with Multiple Parameterizations (Noah-MP; Niu et al. 2011; Yang et al. 2011). Our choice builds on the different degrees of complexity spanned by these models in terms of conceptualization of vegetation, soil and seasonal snowpack (see Table 3 for further details), and also different parameterizations for some hydrologic processes (e.g., different model equations for canopy storage, baseflow, etc.). It should be noted that these models are not 
ordered by degree of complexity, which can vary depending on the process representation of interest (Table 3). Simulation time steps, forcing variables and land cover data used for a priori parameter estimates vary depending on specific model requirements (see Table 2 for further details).

In this study we use a single suite of physics options for Noah-MP, including a Ball-Berry type model for canopy stomatal resistance, the Community Land Model (CLM; Oleson et al. 2010) soil stress function to control stomatal resistance, the SIMTOP model for runoff and groundwater (Niu et al. 2005), a Monin-Obukhov similarity theory-based drag coefficient, supercooled liquid water and frozen soil permeability based on Niu and Yang (2006), a twostream radiation transfer scheme applied only to the vegetated fraction, a snow surface albedo parameterization based on the Canadian Land Surface Scheme (CLASS; Verseghy 1991), partitioning of precipitation into snowfall and rainfall based on Jordan (1991) and a Noah-type lower boundary of soil temperature. Readers are referred to Niu et al. (2011) for a full description of each model component.

\subsection{Experimental design}

\subsubsection{Hydrologic model simulations}

To assess the effects of WRF horizontal resolution and spatial scaling on the portrayal of climate change impacts, we perform offline hydrologic model simulations under historical (CTRL) and modified climate (PGW) scenarios for the following cases:

- Experiment 1: hydrologic models are forced with 4-, 12- and 36-km WRF outputs produced by Rasmussen et al. (2014). 
- Experiment 2: hydrologic models are forced with 4-km WRF outputs, and two additional datasets obtained from re-scaling 4-km outputs to 12 - and $36-\mathrm{km}$ resolutions.

All model simulations are conducted for the period between October 1, 2000 and September 30, 2008, using the first two years as spin up (not processed) to initialize model states. We compute hydrologic changes using the same parameter values obtained by Mendoza et al. (2015), i.e. calibrated by minimizing the root mean squared error (RMSE) between observed and simulated daily streamflow (period October 1, 2002 to September 30, 2008) with the Shuffled Complex Evolution (SCE-UA) algorithm (Duan et al., 1992, 1993), using 4-km resolution WRF historical datasets. Setting WRF-CTRL output as a historical climate baseline fits with the aim to better understand how different methodological choices affect hydrologic portrayals using the climate datasets obtained by Rasmussen et al. (2014); therefore, tuning hydrologic model parameters to WRF-CTRL allows a direct examination of how the climate change signal (given by the differences between WRF-CTRL and WRF-PGW) propagates into hydrologic changes. Although there are still some biases in the WRF-CTRL output (Figure 2), this is a problem common to all historical forcing datasets (Mizukami et al. 2014), including those based on interpolated station data and empirical algorithms (e.g., Maurer et al. 2002; Livneh et al. 2013), and differences between WRF and such gridded datasets are often attributable to errors in the gridded datasets and not to errors in WRF (Gutmann et al. 2012). It is important that hydrologic model parameters are consistent with the features of meteorological fields used, and the highresolution WRF simulations are most consistent with both the observations, and with other WRF simulations.

Because the purpose of these experiments is to examine the implications of forcing datasets developed at different spatial resolutions, we fix the grid spacing of hydrological models to 4- 
$\mathrm{km}$ - identical to the regular grid used in the 4-km WRF simulations performed by Rasmussen et al. (2014) - to isolate effects of forcing scale from those of hydrologic model grid size. Hence, when hydrologic model simulations are forced with 12 - and $36-\mathrm{km}$ meteorological datasets, meteorological variables are distributed to hydrologic model grid cells using a nearest neighbor interpolation method as in Shrestha et al. (2006). Finally, hydrologic changes are computed for the period Oct/2002 - Sep/2008 by forcing all hydrologic models with the same current (CTRL) and future (PGW) WRF datasets.

\subsubsection{Process-based evaluation metrics}

We use four hydrologic signature measures (Yilmaz et al. 2008; Stewart et al. 2005) to quantify model performance and projected changes in catchment behavior. These metrics are intended to represent different hydrologic processes - ranging from overall precipitation partitioning into ET and runoff to vertical redistribution of soil moisture -, and they are derived from daily runoff time series. The notation, short description, mathematical formulation and physical process associated with each signature measure are detailed in Table 4. Similar diagnostic evaluation metrics have been used in past studies with multiple purposes, such as model evaluation (e.g., Herbst et al., 2009; Majone et al., 2012; Pfannerstill et al., 2014), catchment classification (e.g., Oudin et al., 2010; Carrillo et al., 2011; Ley et al., 2011; Sawicz et al., 2011), sensitivity analysis (e.g., van Werkhoven et al., 2008; Wagener et al., 2009), hydrologic model structure identification (e.g., Hartmann et al. 2013; Hrachowitz et al. 2014),

analysis of spatial distribution of hydrologic processes (e.g., McMillan et al. 2014) and the choice of realistic model parameter values in terms of process representations (e.g., Pokhrel and Gupta, 2009; van Werkhoven et al., 2009; Kollat et al., 2012; Pokhrel et al., 2012). 


\section{Results and discussion}

\subsection{Model performance}

We first analyze how hydrologic model performance is affected by WRF horizontal resolution (Figure 4a) and forcing re-scaling (Figure 4b) over the period October/2002 September/2008. To this end, we computed the differences between simulated (control, CTRL) and observed (Obs) values of signature measures of hydrologic behavior (Table 4). In Figure 4, each evaluation metric is displayed in a different row, hydrologic model structures are represented by different symbols, and different colors depict different WRF horizontal resolutions (Figure 4a) or spatial forcing scales (Figure 4b). Therefore, differences between symbols of different colors indicate the magnitudes of effects of RCM horizontal resolution and/or scaling on hydrologic model performance. In Figure 4, the dispersion of red symbols (4$\mathrm{km}$ ) indicates inter-model differences in calibrated model performance, which are still considerable when compared to those from uncalibrated model parameters (Mendoza et al. 2015). Finally, the spread provided by the small multi-model ensemble when using a single meteorological forcing dataset is quantified by the sample standard deviation:

$\mathrm{s}_{\mathrm{M}}=\sqrt{\frac{\sum_{\mathrm{i}=1}^{\mathrm{N}}\left(\mathrm{M}_{\mathrm{i}}-\overline{\mathrm{M}}\right)}{\mathrm{N}-1}}$

where $\mathrm{M}_{\mathrm{i}}$ is the metric value (e.g., runoff ratio) obtained by model $i, N$ is the number of hydrologic model structures $(N=4)$, and $\overline{\mathrm{M}}$ is the mean of the metric obtained from the multimodel ensemble.

The results from experiment 1 (Figure 4a) clearly show the impact of WRF horizontal resolution on water balance simulations. Due to the decreased precipitation amounts from 
coarse-resolution WRF simulations (see 12- and 36-km in Figure 2a), all the hydrologic models produced less runoff in all basins, leading to increased biases (i.e. underestimation) in simulated runoff ratios (RR). When looking at the center of time of runoff (CTR), however, there is no dependence between the selected WRF horizontal resolution and performance, although runoff seasonality is likely to be affected by differences in winter and summer precipitation amounts together with differences in DJF temperatures controlling the simulation of snowpack processes - between 4-km and 12- or 36-km WRF simulations. Using 12- and 36-km WRF outputs increases inter-model differences when comparing to 4-km WRF simulations for all the signatures (Table 5). For example, the sample standard deviations of errors in simulated runoff seasonality (i.e. CTRL - Obs) - computed from the multi-model ensemble forced with the 4-km WRF output - are 2.3, 5.9 and 3.6 days for Yampa, East, and Animas, respectively; however, when using 12-km (36-km) WRF outputs the spread from the multi-model ensemble increases up to 9.4 (18.5) days at Yampa, 8.0 (8.3) days at East, and 7.0 (7.5) days at Animas. Note that the baseflow processes (FLV) result obtained from VIC and the 36-km WRF for the Yampa River basin (i.e. blue triangle) has been omitted in Figure 4a to allow a better visualization and comparison between experiments 1 and 2 (since CTRL - Obs $=4579.4 \log \left(\mathrm{m}^{3} / \mathrm{s}\right)$ ). With the exception of runoff ratio (RR), the degree of improvement or degradation in hydrologic model performance obtained from switching WRF horizontal resolution depends on the combination of hydrologic model and basin.

For the particular case of experiment 2, errors in signature measures reflect how much information is lost when hydrologic model simulations are forced with coarse-scale meteorological fields (Zhao et al. 2009). As shown in Figure 4b, the effects of forcing scaling on model performance exhibit similar patterns to those from WRF horizontal resolution, but 
propagating into generally smaller inter-model differences (Table 5) in runoff ratio (RR), flashiness of runoff (FMS), and baseflow processes (FLV). However, the representation of runoff seasonality (CTR) is considerably affected in some combinations of hydrologic model and basin. For instance, errors in simulated CTR at the Yampa River basin span from 5 day with Noah-LSM and 8.2 days with Noah-MP using 4-km WRF outputs, to -4.2 days with Noah-LSM and -5.6 days with Noah-MP when using the 12-km aggregated dataset. Large changes in simulations of CTR are also observed with PRMS, Noah-LSM and Noah-MP at the East River basin. In summary, forcing scaling can translate into similar or even larger inter-model differences in simulations of runoff seasonality. This might be attributed to the smoothing effect when spatially aggregating high precipitation/snowmelt fields from 4-km WRF output, affecting the historical simulation of high daily runoff events and therefore the computation of center of timing (CTR).

Figure 5 illustrates how hydrologic signature measures obtained from coarse resolution datasets (12- and 36-km) differ from those computed using high-resolution WRF outputs under current climate. The results obtained in experiments 1 and 2 are displayed in Figures 5a and 5b, respectively, where each column represents a specific signature measure, and each row contains signature measures computed with $12-$ and $36-\mathrm{km}$ horizontal resolutions, versus metrics obtained with the 4-km WRF output (i.e. baseline climate dataset). Results from experiment 1 (Figure 5a) demonstrate that while a coarser horizontal resolution propagates into decreased simulated runoff ratios (RR) and a flashier catchment response (FMS) in comparison to the baseline dataset using any hydrologic model, the effects on other metrics depend on the model structure and/or the basin analyzed. For example, 12-km WRF outputs increase the center of time of runoff (CTR) with respect to the 4-km WRF output - from 229 to 235 days at Yampa, from 222 to 231 days at 
East, and from 214 to 227 days at Animas when using PRMS, and decreases the same metric from 227 to 214 days at Yampa, and from 227 to 225 days at East if the model is Noah-MP. Similar effects are observed if hydrologic simulations are forced with 36-km WRF outputs. The implications of WRF horizontal resolution on long-term baseflow (FLV) are basin-dependent for each model with the exception of VIC, for which signature values (all of which have units of $\left.\log \left(\mathrm{m}^{3} / \mathrm{s}\right)\right)$ increase from 523 at Yampa, 292 at East and 225 at Animas - obtained with 4-km WRF output - to 826 (4793) at Yampa, 432 (458) at East, and 376 (464) when using 12-km (36km) WRF outputs.

The results displayed in Figure $5 \mathrm{~b}$ show that the effects of re-scaling forcing datasets are less pronounced than those from WRF horizontal resolution, but still are important for some signature measures. Overall, re-gridding 4-km WRF outputs to coarser horizontal resolutions generates a reduction in simulated runoff ratio (RR) at Yampa (except 36-km with PRMS) and East (except 12-km and Noah-LSM), and shifts to earlier center of time of runoff (CTR) at Yampa with all hydrologic models, and decreases in CTR at East and Animas with all models except VIC. Scaling effects translate into generally small variations in FMS (except at the Yampa River basin when forcing VIC with $12-\mathrm{km}$ and $36-\mathrm{km}$ datasets, and East when forcing VIC with 36-km WRF), with increases or decreases depending on the combination of hydrologic model and basin. For instance, the $12-\mathrm{km}(36-\mathrm{km})$ dataset shows decreases in FMS (all values with units of $\log \left(\mathrm{m}^{3} / \mathrm{s}\right)$ ) from 1.21 to 1.17 (1.15) when running PRMS at the Animas River basin, but increases the same metric from 1.23 to 1.28 (1.33) if the hydrologic model is VIC. Further, the 12-km forcing dataset increases FMS from 1.59 to 1.61 at the Yampa River basin, and from 1.35 to 1.37 at the East River basin when hydrologic simulations are performed with PRMS. Finally, scaling effects on long-term baseflow (FLV) are more pronounced when the 
forcing grid size is $36-\mathrm{km}$, with increase or decrease in signature values depending on the combination of forcing scale and hydrologic model structure at each basin.

\subsection{Changes in annual water balance}

In this section, we examine and compare the effects of WRF horizontal resolution (experiment 1) and spatial forcing aggregation (experiment 2) on the partitioning of precipitation into ET and runoff under current and future climate scenarios. In each panel of Figure 6, the diagonal lines represent basin-averaged mean annual precipitation for current and future climate scenarios over a 6-year average period (Oct/2002 - Sep/2008). The intersection of these lines with the $\mathrm{x}$-axis indicates where all precipitation becomes runoff, while the intersection with the y-axis indicates where the system converts all precipitation into ET. In each panel, different symbols depict outputs coming from different hydrologic model structures for current climate (unfilled) and future climate (solid) with symbol colors showing the spatial resolutions. A symbol located exactly on the 1:1 lines represents a simulation with negligible changes in storage over the 6-year simulation period (i.e. $\mathrm{P}=\mathrm{ET}+\mathrm{R}$ ), whereas symbols located below the 1:1 line imply increases in storage, and those above denote decreases in storage. Inter-model differences in precipitation partitioning are represented by the distance between different symbols (unfilled or solid), while the distance between a particular symbol (e.g., star for Noah-MP) for current (unfilled) and future (solid) climate scenarios represents the hydrologic change signal. The uncertainty arising from model choice, represented by the dispersion of symbols holding the same color along the precipitation (diagonal) line, is quantified in Table 6 by the following metric:

$$
s_{R, E T}=\sqrt{\sigma_{R}^{2}+\sigma_{E T}^{2}}
$$


where $\sigma_{R}$ and $\sigma_{E T}$ are the sample standard deviations obtained with equation (1) from the multimodel outputs for mean annual runoff and mean annual ET, respectively.

The results obtained from experiment 1 (Figure 6a and Figure 2a) show that 4-km WRF simulations generate the largest precipitation amounts under current (CTRL) and future (PGW) climate scenarios at all basins, followed by 12- and 36-km WRF outputs. On the other hand, the effects of forcing re-scaling (Figure 6b) on basin-averaged annual precipitation are reduced compared to those of WRF horizontal resolution. Interestingly, forcing re-scaling can increase inter-model differences (i.e. larger dispersion of symbols when 4-km WRF are re-gridded to 12and 36-km) in precipitation partitioning under current and future climate (Table 6). For example, $s_{R, E T}$ increases from $40.5 \mathrm{~mm} /$ year with 4-km WRF-CTRL output, to $45.5 \mathrm{~mm} /$ year with the 12 km aggregated dataset in the East River basin. Further, scaling effects on inter-model differences can be larger than those from WRF horizontal resolution. For instance, $s_{R, E T}=41.3 \mathrm{~mm} / \mathrm{year}$ when using 36-km WRF-CTRL output at the Yampa River basin, but the same metric goes up to $51.7 \mathrm{~mm} /$ year with the $36-\mathrm{km}$ aggregated dataset.

To understand how WRF horizontal resolution and forcing re-scaling affect the portrayal of climate change impacts in annual water balance, we compute projected changes in basinaveraged mean annual runoff and ET (Figure 7) for each basin (displayed in different columns). In each panel, the dispersion of the same symbol (e.g., triangle for VIC) holding different colors across the $\Delta$ Runoff $-\Delta$ ET space (with $\Delta$ representing the difference between future and current climate scenarios) represents the uncertainty introduced by the choice of WRF horizontal resolution (Figure 7a) or spatial resolution in forcing datasets (Figure 7b). Similarly, the dispersion of different symbols holding the same color (e.g., red for 4-km WRF datasets) illustrates the uncertainty associated with hydrologic model choice. We quantify inter-model 
differences in projected changes in annual water balance using equation (2), together with interforcing differences when a single model structure is applied (Table 7).

Figure 7a shows that the choice of WRF horizontal resolution has large effects on hydrologic changes projected through different hydrologic model structures. These effects are reflected in the magnitude (i.e. location or distance from each symbol to the point $\Delta$ Runoff $=0$ $\mathrm{mm} / \mathrm{yr}, \Delta \mathrm{ET}=0 \mathrm{~mm} / \mathrm{yr}$ ) and direction (i.e. quadrant in which symbols are located, indicating increase/decrease of mean annual runoff and ET) of projected changes in mean annual runoff and mean annual ET obtained with each hydrologic model. Further, the dispersion provided by different WRF horizontal resolutions - represented by different colors and quantified in Table 7b - through a single model structure -represented by a single symbol in Figure 7a - may be comparable or even larger than that obtained from multiple model structures forced with a unique WRF dataset (Table 7a). For example, inter-forcing differences in projected hydrologic changes at the East River basin from experiment 1 (i.e. different WRF horizontal resolutions) are $s_{\triangle R, \triangle E T}=28.5 \mathrm{~mm} /$ year using PRMS, and $s_{\triangle R, \Delta E T}=22.6 \mathrm{~mm} /$ year with Noah-MP. Both values are larger than inter-model differences obtained using 12-km WRF outputs, for which $s_{\triangle R, \Delta E T}=16.7$ $\mathrm{mm} /$ year. Further, in most cases inter-forcing differences from experiment 2 (i.e. different forcing scales) are smaller than inter-model differences summarized in Table $7 \mathrm{a}$.

In summary, the results presented Figure 7 in Table 7 indicate that the effects of forcing scaling on projected changes in the annual water balance are smaller than those coming from WRF horizontal resolution. Indeed, the direction of hydrologic change is mostly preserved when forcing the same hydrologic model with re-scaled datasets (Figure 7b). In opposition to the results obtained from experiment 1 , the uncertainty coming from hydrologic model choice is much larger than the uncertainty from the choice of dataset. Additionally, re-scaling forcing 
inputs to coarser resolutions can enhance inter-model differences in hydrologic change shown by the increased dispersion of symbols of the same color and $s_{\triangle R, \Delta E T}$ values (Table 7).

\subsection{Projected changes in catchment behavior}

Finally, we compare the effects of WRF horizontal resolution and forcing re-scaling on projected changes in hydrologic signature measures across multiple model structures (Figure 8). Again, differences between symbols of different colors indicate the magnitudes of effects of RCM horizontal resolution and/or scaling on projected changes in basin behavior. The results from experiment 1 (Figure 8a) show that the only consistent change obtained with all WRF horizontal resolutions is a decrease in the center of time of runoff (CTR), or earlier annual peak flow, under the future climate scenario, although the magnitudes obtained can be different depending on the hydrologic model selected. These inter-model differences - computed with equation (1) for each forcing dataset - are presented in Table 8. One can note that - as opposed to model performance results (Table 5) - there is not a defined relation between the choice of WRF horizontal resolution, and the spread in projected changes from different hydrologic model structures.

Selecting coarser grid sizes (i.e. $12-$ and $36-\mathrm{km}$ ) with a convective parameterization in WRF generally translates into increased projected changes (i.e. PGW - CTRL) in runoff ratio (RR), changing in some cases the sign (i.e. from negative to positive values) of projected variations. For instance, outputs from the 4-km WRF solution show a decrease in RR of -0.01 with PRMS at the Yampa River basin, but outputs from the 12-km (36-km) WRF solution show a change of $+0.02(+0.03)$ for the same model/basin. When looking at flashiness of runoff (FMS), the effects of WRF horizontal resolution on projected changes obtained with a specific 
hydrologic model structure depend on the basin analyzed. For example, the choice of grid spacing has relatively small effects on projected changes in FMS obtained with Noah-LSM at Yampa $\left(+0.27\right.$ to $\left.+0.36 \log \left(\mathrm{m}^{3} / \mathrm{s}\right)\right)$, Noah-MP at East $\left(+0.03\right.$ to $\left.+0.08 \log \left(\mathrm{m}^{3} / \mathrm{s}\right)\right)$, and PRMS at Animas (-0.18 to $\left.-0.27 \log \left(\mathrm{m}^{3} / \mathrm{s}\right)\right)$, but larger implications in future projections for the rest of models/basins. The results for low flow volumes (FLV) show that WRF horizontal resolution mostly affects the direction and magnitude of projections obtained with VIC, especially in the Yampa River basin, for which projected changes go from $+87.1 \log \left(\mathrm{m}^{3} / \mathrm{s}\right)$ with $4-\mathrm{km}$ WRF output, to $-65.3 \log \left(\mathrm{m}^{3} / \mathrm{s}\right)$ using $36-\mathrm{km}$ WRF datasets. This behavior can be explained by the parameter values found from the calibration of VIC at Yampa, which compensated a good match of high flows at the expense of very poor baseflow simulations during July-September (not shown).

According to Figure $8 \mathrm{~b}$, while the effects of forcing re-scaling on projected changes in runoff ratio (RR) are smaller than those from WRF horizontal resolution (Figure 8a), they can still change the sign (e.g., VIC simulations at the Yampa River basin) and magnitude (e.g., PRMS and VIC at East, Noah-MP at Animas) of projections. Although forcing scaling has very minor effects on changes in runoff seasonality (CTR) across all models, it can affect both the magnitude and direction of projections in flashiness of runoff (FMS). For example, projected changes at the East River basin with VIC span from $+0.34 \log \left(\mathrm{m}^{3} / \mathrm{s}\right)$ with 4-km WRF output, to $0.15 \log \left(\mathrm{m}^{3} / \mathrm{s}\right)$ using $36-\mathrm{km}$ re-scaled datasets; and projected changes in FMS at the Animas River basin with Noah-MP range from $-0.04 \log \left(\mathrm{m}^{3} / \mathrm{s}\right)$ with $4-\mathrm{km}$ WRF output, to +0.02 $\log \left(\mathrm{m}^{3} / \mathrm{s}\right)$ using $36-\mathrm{km}$ re-scaled datasets. Finally, scaling effects on projected changes in low flow volumes (FLV) are generally smaller than those from WRF horizontal resolution, and are mostly reflected in VIC simulations. Nevertheless, other hydrologic model structures can also 
reverse the signal of projected changes of FLV in some basins; for instance, Noah-LSM projects a variation of $+33.4 \log \left(\mathrm{m}^{3} / \mathrm{s}\right)$ at the Animas River basin using 4-km WRF outputs, switching to $31.2 \log \left(\mathrm{m}^{3} / \mathrm{s}\right)$ if $36-\mathrm{km}$ aggregated datasets are used.

\section{Summary and Conclusions}

Hydrologists encounter many subjective decisions when configuring hydrologic models for climate change impact studies. One of the choices is how forcing inputs are prepared to drive hydrologic model simulations. Scaling (up-scaling) high-resolution climate model output is typically done to match up with the resolutions of other hydrologic model inputs, such as parameter fields. Furthermore, climate modelers often use different microphysics schemes (e.g., convection parameterization or explicit solution of physical equations) depending on spatial resolution, affecting precipitation inputs. We investigated the implications that RCM horizontal resolution and re-scaling of RCM outputs may have on the portrayal of climate change impacts. Specifically, we assessed the effects of the above decisions on: (i) historical performance in terms of hydrologic signature measures, and (ii) hydrologic changes due to a climate perturbation, with focus on the annual water balance and catchment processes. The analyses were conducted in three catchments located in the headwaters of the Colorado River basin. To explore the interplay between forcing effects and hydrologic model choice, we include four model structures, whose parameters were calibrated against observed runoff using 4-km WRF historical datasets (Mendoza et al. 2015).

As illustrated by Rasmussen et al. (2014), the choice of WRF horizontal resolution (i.e. model grid size and inclusion of convective parameterization) has large effects on simulated precipitation amounts. Specifically, the use of 12 - and $36-\mathrm{km}$ resolutions and a convective 
parameterization results in the underestimation of basin-averaged annual precipitation totals with respect to 4-km WRF simulations. Therefore, it was found that the choice of WRF spatial resolution has larger effects on the historical simulation of hydrologic signature measures in comparison to those provided by up-scaling forcing datasets. However, up-scaling still affects runoff seasonality (CTR) considerably due to the smoothing effects on high spatial variability in precipitation and temperature over the mountainous, changing snowmelt timing. This is in line with the results of Lobligeois et al. (2014), who found that using high-resolution precipitation fields mostly benefited hydrologic simulations in areas with highly heterogeneous rainfall patterns.

The water balance analysis revealed that WRF horizontal resolution has tremendous effects on the portrayal of hydrologic change at an annual basis (i.e. variations in mean annual runoff and ET), regardless of the hydrologic model structure selected. Moreover, the effects of WRF horizontal resolution on hydrologic change may overwhelm the uncertainty from model choice, which surpasses the uncertainty from re-scaled forcings. It was also found that re-scaling forcing datasets to coarser resolutions may augment inter-model differences in precipitation partitioning and projected changes in runoff and ET. The same conclusions can be drawn from hydrologic model simulations conducted with uncalibrated parameter values (not shown here).

Forcing scaling effects on projected changes in hydrologic signature measures were found to be generally smaller than those coming from WRF horizontal resolution. However, using coarser forcing resolutions may create an artificial switch in the sign of changes projected by a particular hydrologic model structure (e.g., runoff ratio, flashiness of runoff). Even more, we found that scaling effects can exceed those associated with WRF spatial resolution when projecting variations in hydrologic behavior (e.g., flashiness of runoff). 
This study has shown that the horizontal grid spacing used in RCMs can have important consequences on the magnitude and direction of the hydrologic change signal; however, this specific uncertainty source is still only one part of the entire uncertainty envelope of simulated hydrologic projections (Clark et al. 2016). For example, a relevant component excluded from our analyses is hydrologic parameter uncertainty (e.g., Cameron et al. 1999; Wilby 2005; SteeleDunne et al. 2008; Surfleet and Tullos 2013; Mendoza et al. 2016). Earlier work in our group and by others has shown that the choice of forcing scale may have large effects on calibrated parameters - especially for precipitation (e.g., Liang et al. 2004; Bárdossy and Das 2008; Tramblay et al. 2011) -, and that forcing generation methods may have substantial implications

on hydrological portrayals (Wayand et al. 2013; Mizukami et al. 2014; Elsner et al. 2014), meaning that parameter values could be considerably affected when calibrating hydrologic models against re-scaled datasets. In order to avoid an over-confident portrayal of climate change impacts, future studies should incorporate an integrated characterization and quantification of the different sources of uncertainty in hydrologic modeling, with particular emphasis on meteorological forcings, model structure, and parameters.

\section{Acknowledgments}

We thank Marketa Elsner, Andy Newman, Michael Barlage, Roland Viger, Adam Carheden and Tor Mohling for their feedback and assistance for setting up the models. This work was supported through a contract with the U.S. Army Corps of Engineers, through a Cooperative Agreement with the U.S. Bureau Of Reclamation, and through a graduate fellowship from the Cooperative Institute for Research and Environmental Sciences (CIRES). The National Center for Atmospheric Research is sponsored by the National Science Foundation. Finally, we thank 
two anonymous reviewers for their highly constructive comments, which contributed to improve this manuscript considerably.

\section{References}

Addor, N., O. Rössler, N. Köplin, M. Huss, R. Weingartner, and J. Seibert, 2014: Robust changes and sources of uncertainty in the projected hydrological regimes of Swiss catchments. Water Resour. Res., 50, 7541-7562, doi:10.1002/2014WR015549.

Arnaud, P., C. Bouvier, L. Cisneros, and R. Dominguez, 2002: Influence of rainfall spatial variability on flood prediction. J. Hydrol, 260, 216-230, doi:10.1016/S00221694(01)00611-4.

Bae, D.-H., I.-W. Jung, and D. P. Lettenmaier, 2011: Hydrologic uncertainties in climate change from IPCC AR4 GCM simulations of the Chungju Basin, Korea. J. Hydrol., 401, 90-105, doi:10.1016/j.jhydrol.2011.02.012.

Bárdossy, A., and T. Das, 2008: Influence of rainfall observation network on model calibration and application. Hydrol. Earth Syst. Sci., 12, 77-89, doi:10.5194/hessd-3-3691-2006.

Barlage, M., and Coauthors, 2010: Noah land surface model modifications to improve snowpack prediction in the Colorado Rocky Mountains. J. Geophys. Res., 115, D22101, doi:10.1029/2009JD013470.

Bastola, S., C. Murphy, and J. Sweeney, 2011: The role of hydrological modelling uncertainties in climate change impact assessments of Irish river catchments. Adv. Water Resour., 34, 562-576, doi:10.1016/j.advwatres.2011.01.008.

Bell, V. A., and R. J. Moore, 2000: The sensitivity of catchment runoff models to rainfall data at different spatial scales. Hydrol. Earth Syst. Sci., 4, 653-667, doi:10.5194/hess-4-653-2000.

Boorman, D., and C. Sefton, 1997: Recognising the uncertainty in the quantification of the effects of climate change on hydrological response. Clim. Change, 35, 415-434.

Bureau of Reclamation, 2012: Colorado River Basin Water Supply and Demand Study: Technical Report B - Water Supply Assessment.

Cameron, D., K. Beven, and P. Naden, 1999: Flood frequency estimation by continuous simulation under climate change (with uncertainty). Hydrol. Earth Syst. Sci., 4, 393-405.

Carrillo, G., P. A. Troch, M. Sivapalan, T. Wagener, C. Harman, and K. Sawicz, 2011: Catchment classification: hydrological analysis of catchment behavior through processbased modeling along a climate gradient. Hydrol. Earth Syst. Sci., 15, 3411-3430, 
doi:10.5194/hess-15-3411-2011.

Chen, F., and J. Dudhia, 2001: Coupling an Advanced Land Surface-Hydrology Model with the Penn State-NCAR MM5 Modeling System. Part I: Model Implementation and Sensitivity. Mon. Weather Rev., 129, 569-585, doi:10.1175/15200493(2001)129<0569:CAALSH>2.0.CO;2.

Christensen, N. S., and D. P. Lettenmaier, 2007: A multimodel ensemble approach to assessment of climate change impacts on the hydrology and water resources of the Colorado River Basin. Hydrol. Earth Syst. Sci., 11, 1417-1434, doi:10.5194/hess-11-1417-2007.

Clark, M. P., and Coauthors, 2016: Characterizing Uncertainty of the Hydrologic Impacts of Climate Change. Curr. Clim. Chang. Reports, 2, 55-64, doi:10.1007/s40641-016-0034-x.

Collins, W. D., and Coauthors, 2006: The Community Climate System Model Version 3 (CCSM3). J. Clim., 19, 2122-2143, doi:10.1175/JCLI3761.1.

Dankers, R., O. B. Christensen, L. Feyen, M. Kalas, and A. de Roo, 2007: Evaluation of very high-resolution climate model data for simulating flood hazards in the Upper Danube Basin. J. Hydrol., 347, 319-331, doi:10.1016/j.jhydrol.2007.09.055.

Ek, M. B., 2003: Implementation of Noah land surface model advances in the National Centers for Environmental Prediction operational mesoscale Eta model. J. Geophys. Res., 108, 116, doi:10.1029/2002JD003296.

Elsner, M. M., S. Gangopadhyay, T. Pruitt, L. D. Brekke, N. Mizukami, and M. P. Clark, 2014: How Does the Choice of Distributed Meteorological Data Affect Hydrologic Model Calibration and Streamflow Simulations? J. Hydrometeorol., 15, 1384-1403, doi:10.1175/JHM-D-13-083.1.

Finnerty, B. D., M. B. Smith, D.-J. Seo, V. Koren, and G. E. Moglen, 1997: Space-time scale sensitivity of the Sacramento model to radar-gage precipitation inputs. J. Hydrol., 203, 2138, doi:10.1016/S0022-1694(97)00083-8.

Fowler, H. J., S. Blenkinsop, and C. Tebaldi, 2007: Linking climate change modelling to impacts studies: recent advances in downscaling techniques for hydrological modelling. Int. J. Climatol., 27, 1547-1578, doi:10.1002/joc.1556. http://doi.wiley.com/10.1002/joc.1556.

Fry, J., and Coauthors, 2011: Completion of the 2006 National Land Cover Database for the Conterminous United States. Photogramm. Eng. Remote Sens., 77, 858-864.

Gao, Y., J. a. Vano, C. Zhu, and D. P. Lettenmaier, 2011: Evaluating climate change over the Colorado River basin using regional climate models. J. Geophys. Res., 116, D13104, doi:10.1029/2010JD015278.

Graham, L. P., J. Andréasson, and B. Carlsson, 2007: Assessing climate change impacts on 
hydrology from an ensemble of regional climate models, model scales and linking methods - a case study on the Lule River basin. Clim. Change, 81, 293-307, doi:10.1007/s10584006-9215-2.

Gutmann, E. D., R. M. Rasmussen, C. Liu, K. Ikeda, D. J. Gochis, M. P. Clark, J. Dudhia, and G. Thompson, 2012: A Comparison of Statistical and Dynamical Downscaling of Winter Precipitation over Complex Terrain. J. Clim., 25, 262-281, doi:10.1175/2011JCLI4109.1.

Hansen, M. C., R. S. DeFries, J. R. Townshend, and R. Sohlberg, 2000: Global land cover classification at $1 \mathrm{~km}$ spatial resolution using a classification tree approach. Int. J. Remote Sens., 21, 1331-1364.

Hara, M., T. Yoshikane, H. Kawase, and F. Kimura, 2008: Estimation of the Impact of Global Warming on Snow Depth in Japan by the Pseudo-Global-Warming Method. Hydrol. Res. Lett., 2, 61-64, doi:10.3178/hrl.2.61.

Hartmann, A., T. Wagener, A. Rimmer, J. Lange, H. Brielmann, and M. Weiler, 2013: Testing the realism of model structures to identify karst system processes using water quality and quantity signatures. Water Resour. Res., 49, 3345-3358, doi:10.1002/wrcr.20229.

Herbst, M., H. V. Gupta, and M. C. Casper, 2009: Mapping model behaviour using SelfOrganizing Maps. Hydrol. Earth Syst. Sci., 13, 395-409.

Hoerling, M., and J. Eischeid, 2007: Past peak water in the Southwest. Southwest Hydrol., 6, 18 19.

Hong, S.-Y., Y. Noh, and J. Dudhia, 2006: A New Vertical Diffusion Package with an Explicit Treatment of Entrainment Processes. Mon. Weather Rev., 134, 2318-2341, doi:10.1175/MWR3199.1.

Hrachowitz, M., and Coauthors, 2014: Process consistency in models: The importance of system signatures, expert knowledge, and process complexity. Water Resour. Res., 50, 7445-7469, doi:10.1002/2014WR015484.

Ikeda, K., and Coauthors, 2010: Simulation of seasonal snowfall over Colorado. Atmos. Res., 97, 462-477, doi:10.1016/j.atmosres.2010.04.010.

Janjić, Z., 1994: The Step-Mountain Eta Coordinate Model: Further Developments of the Convection, Viscous Sublayer, and Turbulence Closure Schemes. Mon. Weather Rev., 122, 927-945.

Jensen, M., D. Rob, and C. Franzoy, 1969: Scheduling irrigations using climate-crop-soil data. National Conference on Water Resources Engineering of the American Society of Civil Engineers, New Orleans, 20.

Jiang, T., Y. D. Chen, C. Xu, X. Chen, X. Chen, and V. P. Singh, 2007: Comparison of 
hydrological impacts of climate change simulated by six hydrological models in the

Dongjiang Basin, South China. J. Hydrol., 336, 316-333, doi:10.1016/j.jhydrol.2007.01.010.

Jones, R. N., F. H. S. Chiew, W. C. Boughton, and L. Zhang, 2006: Estimating the sensitivity of mean annual runoff to climate change using selected hydrological models. Adv. Water Resour., 29, 1419-1429, doi:10.1016/j.advwatres.2005.11.001.

Jordan, R., 1991: A One-Dimensional Temperature Model for a Snow Cover. Cold Reg. Res. Eng. Lab, U.S. Army Corps Eng. Hanover, N.H., Spec. Rept. 91-16.

Kawase, H., T. Yoshikane, M. Hara, F. Kimura, T. Yasunari, B. Ailikun, H. Ueda, and T. Inoue, 2009: Intermodel variability of future changes in the Baiu rainband estimated by the pseudo global warming downscaling method. J. Geophys. Res., 114, D24110, doi:10.1029/2009JD011803.

Kay, A. L., H. N. Davies, V. A. Bell, and R. G. Jones, 2009: Comparison of uncertainty sources for climate change impacts: flood frequency in England. Clim. Change, 92, 41-63, doi:10.1007/s10584-008-9471-4.

Kleinn, J., C. Frei, J. Gurtz, D. Lüthi, P. L. Vidale, and C. Schär, 2005: Hydrologic simulations in the Rhine basin driven by a regional climate model. J. Geophys. Res. D Atmos., 110, 118, doi:10.1029/2004JD005143.

Kollat, J. B., P. M. Reed, and T. Wagener, 2012: When are multiobjective calibration trade-offs in hydrologic models meaningful? Water Resour. Res., 48, 1-19, doi:10.1029/2011WR011534.

Koren, V. I., B. D. Finnerty, J. C. Schaake, M. B. Smith, D.-J. Seo, and Q.-Y. Duan, 1999: Scale dependencies of hydrologic models to spatial variability of precipitation. J. Hydrol., 217, 285-302, doi:10.1016/S0022-1694(98)00231-5.

Lauer, A., C. Zhang, O. Elison-Timm, Y. Wang, and K. Hamilton, 2013: Downscaling of climate change in the hawaii region using CMIP5 results: On the choice of the forcing fields*. $J$. Clim., 26, 10006-10030, doi:10.1175/JCLI-D-13-00126.1.

Leavesley, G. H., and L. G. Stannard, 1995: The precipitation-runoff modeling system-PRMS. Computer Models of Watershed Hydrology, V.P. Singh, Ed., Water Resources Publications, Highlands Ranch, CO, 281-310.

Leavesley, G. H., R. W. Lichty, B. M. Troutman, and L. G. Saindon, 1983: Precipitation-Runoff Modeling System: User's Manual.

Ley, R., M. C. Casper, H. Hellebrand, and R. Merz, 2011: Catchment classification by runoff behaviour with self-organizing maps (SOM). Hydrol. Earth Syst. Sci., 15, 2947-2962, 
doi:10.5194/hess-15-2947-2011.

Liang, X., D. P. Lettenmaier, E. F. Wood, and S. J. Burges, 1994: A simple hydrologically based model of land surface water and energy fluxes for general circulation models. J. Geophys. Res., 99, 14,415.14.428.

— - E. F. Wood, and D. P. Lettenmaier, 1996: Surface soil moisture parameterization of the VIC-2L model: Evaluation and modification. Glob. Planet. Change, 13, 195-206, doi:10.1016/0921-8181(95)00046-1.

— J. Guo, and L. R. Leung, 2004: Assessment of the effects of spatial resolutions on daily water flux simulations. J. Hydrol., 298, 287-310, doi:10.1016/j.jhydrol.2003.07.007.

Livneh, B., E. A. Rosenberg, C. Lin, B. Nijssen, V. Mishra, K. M. Andreadis, E. P. Maurer, and D. P. Lettenmaier, 2013: A long-term hydrologically based dataset of land surface fluxes and states for the conterminous United States: Update and extensions. J. Clim., 26, 93849392, doi:10.1175/JCLI-D-12-00508.1.

Lobligeois, F., V. Andréassian, C. Perrin, P. Tabary, and C. Loumagne, 2014: When does higher spatial resolution rainfall information improve streamflow simulation? An evaluation using 3620 flood events. Hydrol. Earth Syst. Sci., 18, 575-594, doi:10.5194/hess-18-575-2014.

Ludwig, R., and Coauthors, 2009: The role of hydrological model complexity and uncertainty in climate change impact assessment. Adv. Geosci., 21, 63-71.

Majone, B., C. I. Bovolo, A. Bellin, S. Blenkinsop, and H. J. Fowler, 2012: Modeling the impacts of future climate change on water resources for the Gállego river basin (Spain). Water Resour. Res., 48, W01512, doi:10.1029/2011WR010985.

Maurer, E., A. W. Wood, and D. P. Lettenmaier, 2002: A Long-Term Hydrologically Based Dataset of Land Surface Fluxes and States for the Conterminous United States. J. Clim., 15, $3237-3251$.

McMillan, H., M. Gueguen, E. Grimon, R. Woods, M. Clark, and D. E. Rupp, 2014: Spatial variability of hydrological processes and model structure diagnostics in a $50 \mathrm{~km} 2$ catchment. Hydrol. Process., 28, 4896-4913, doi:10.1002/hyp.9988.

Meehl, G. A., C. Covey, K. E. Taylor, T. Delworth, R. J. Stouffer, M. Latif, B. McAvaney, and J. F. B. Mitchell, 2007: THE WCRP CMIP3 Multimodel Dataset: A New Era in Climate Change Research. Bull. Am. Meteorol. Soc., 88, 1383-1394, doi:10.1175/BAMS-88-9-1383.

Mendoza, P. A., and Coauthors, 2015: Effects of hydrologic model choice and calibration on the portrayal of climate change impacts. J. Hydrometeorol., 16, 762-780, doi:10.1175/JHM-D14-0104.1.

Mendoza, P. A., M. P. Clark, N. Mizukami, E. D. Gutmann, J. R. Arnold, L. D. Brekke, and B. 
Rajagopalan, 2016: How do hydrologic modeling decisions affect the portrayal of climate change impacts? Hydrol. Process., 30, 1071-1095, doi:10.1002/hyp.10684. http://doi.wiley.com/10.1002/hyp.10684.

Mesinger, F., and Coauthors, 2006: North American Regional Reanalysis. Bull. Am. Meteorol. Soc., 87, 343-360, doi:10.1175/BAMS-87-3-343.

Miller, W., R. A. Butler, T. Piechota, J. Prairie, K. Grantz, and G. DeRosa, 2012: Water Management Decisions using Multiple Hydrologic Models Within the San Juan River Basin Under Changing Climate Conditions. J. Water Resour. Plan. Manag., 138, 412-420, doi:10.1061/(ASCE)WR.1943-5452.0000237.

Miller, W. P., T. C. Piechota, S. Gangopadhyay, and T. Pruitt, 2011: Development of streamflow projections under changing climate conditions over Colorado River basin headwaters. Hydrol. Earth Syst. Sci., 15, 2145-2164, doi:10.5194/hess-15-2145-2011.

Milly, P. C. D., K. A. Dunne, and A. V Vecchia, 2005: Global pattern of trends in streamflow and water availability in a changing climate. Nature, 438, 347-350, doi:10.1038/nature04312.

Mitchell, K. E., and Coauthors, 2004: The multi-institution North American Land Data Assimilation System (NLDAS): Utilizing multiple GCIP products and partners in a continental distributed hydrological modeling system. J. Geophys. Res., 109, D07S90, doi:10.1029/2003JD003823.

Mizukami, N., and Coauthors, 2014: Hydrologic Implications of Different Large-Scale Meteorological Model Forcing Datasets in Mountainous Regions. J. Hydrometeorol., 15, 474-488, doi:10.1175/JHM-D-13-036.1.

—, and Coauthors, 2016: Implications of the Methodological Choices for Hydrologic Portrayals of Climate Change over the Contiguous United States: Statistically Downscaled Forcing Data and Hydrologic Models. J. Hydrometeorol., 17, 73-98, doi:10.1175/JHM-D14-0187.1. http://journals.ametsoc.org/doi/abs/10.1175/JHM-D-14-0187.1.

Najafi, M. R., H. Moradkhani, and I. W. Jung, 2011: Assessing the uncertainties of hydrologic model selection in climate change impact studies. Hydrol. Process., 25, 2814-2826, doi:10.1002/hyp.8043.

Nakicenovic, N., and Coauthors, 2000: IPCC Special Report on Emissions Scenarios. Cambridge Univ. Press, Cambridge, UK, 612 pp.

Niu, G., and Z. Yang, 2006: Effects of frozen soil on snowmelt runoff and soil water storage at a continental scale. J. Hydrometeorol., 937-953.

Niu, G.-Y., Z.-L. Yang, R. E. Dickinson, and L. E. Gulden, 2005: A simple TOPMODEL-based 
runoff parameterization (SIMTOP) for use in global climate models. J. Geophys. Res., 110, D21106, doi:10.1029/2005JD006111.

—, and Coauthors, 2011: The community Noah land surface model with multiparameterization options (Noah-MP): 1. Model description and evaluation with localscale measurements. J. Geophys. Res., 116, D12109, doi:10.1029/2010JD015139.

Oleson, K. W., and Coauthors, 2010: Technical Description of version 4.0 of the Community Land Model (CLM). Boulder, Colorado, USA, 257 pp.

Olsson, J., P. Berg, and A. Kawamura, 2015: Impact of RCM Spatial Resolution on the Reproduction of Local, Subdaily Precipitation. J. Hydrometeorol., 16, 534-547, doi:10.1175/JHM-D-14-0007.1.

Oudin, L., A. Kay, V. Andréassian, and C. Perrin, 2010: Are seemingly physically similar catchments truly hydrologically similar? Water Resour. Res., 46, W11558, doi:10.1029/2009WR008887.

Pfannerstill, M., B. Guse, and N. Fohrer, 2014: Smart low flow signature metrics for an improved overall performance evaluation of hydrological models. J. Hydrol., 510, 447-458, doi:10.1016/j.jhydrol.2013.12.044.

Pokhrel, P., and H. V. Gupta, 2009: Regularized calibration of a distributed hydrological model using available information about watershed properties and signature measures. New Approaches to Hydrological Prediction in Data-sparse Regions (Proc. of Symposium HS.2 at the Joint IAHS and IAH Convention, Hyderabad, India, September 2009), 20-25.

—, K. K. Yilmaz, and H. V. Gupta, 2012: Multiple-criteria calibration of a distributed watershed model using spatial regularization and response signatures. J. Hydrol., 418-419, 49-60, doi:10.1016/j.jhydrol.2008.12.004.

Poulin, A., F. Brissette, R. Leconte, R. Arsenault, and J.-S. Malo, 2011: Uncertainty of hydrological modelling in climate change impact studies in a Canadian, snow-dominated river basin. J. Hydrol., 409, 626-636, doi:10.1016/j.jhydrol.2011.08.057.

Prein, A. F., G. J. Holland, R. M. Rasmussen, J. Done, K. Ikeda, M. P. Clark, and C. H. Liu, 2013: Importance of Regional Climate Model Grid Spacing for the Simulation of Heavy Precipitation in the Colorado Headwaters. J. Clim., 26, 4848-4857, doi:10.1175/JCLI-D-1200727.1.

Prudhomme, C., and H. Davies, 2009: Assessing uncertainties in climate change impact analyses on the river flow regimes in the UK. Part 2: future climate. Clim. Change, 93, 197-222, doi:10.1007/s10584-008-9461-6.

Rasmussen, R., and Coauthors, 2011: High-Resolution Coupled Climate Runoff Simulations of 
Seasonal Snowfall over Colorado: A Process Study of Current and Warmer Climate. $J$. Clim., 24, 3015-3048, doi:10.1175/2010JCLI3985.1.

— , and Coauthors, 2014: Climate Change Impacts on the Water Balance of the Colorado Headwaters: High-Resolution Regional Climate Model Simulations. J. Hydrometeorol., 15, 1091-1116, doi:10.1175/JHM-D-13-0118.1.

Rasmussen, S. H., J. H. Christensen, M. Drews, D. J. Gochis, and J. C. Refsgaard, 2012: SpatialScale Characteristics of Precipitation Simulated by Regional Climate Models and the Implications for Hydrological Modeling. J. Hydrometeorol., 13, 1817-1835, doi:10.1175/JHM-D-12-07.1. http://journals.ametsoc.org/doi/abs/10.1175/JHM-D-12-07.1.

Ray, A., J. Barsugli, K. Averyt, K. Wolter, M. Hoerling, N. Doesken, B. Udall, and R. Webb, 2008: Climate change in Colorado: a synthesis to support water resources management and adaptation. $52 \mathrm{pp}$.

van Roosmalen, L., J. H. Christensen, M. B. Butts, K. H. Jensen, and J. C. Refsgaard, 2010: An intercomparison of regional climate model data for hydrological impact studies in Denmark. J. Hydrol., 380, 406-419, doi:10.1016/j.jhydrol.2009.11.014.

Sawicz, K., T. Wagener, M. Sivapalan, P. A. Troch, and G. Carrillo, 2011: Catchment classification: empirical analysis of hydrologic similarity based on catchment function in the eastern USA. Hydrol. Earth Syst. Sci., 15, 2895-2911, doi:10.5194/hess-15-2895-2011.

Schär, C., C. Frei, D. Lüthi, and H. C. Davies, 1996: Surrogate climate-change scenarios for regional climate models. Geophys. Res. Lett., 23, 669-672, doi:10.1029/96GL00265.

Shrestha, R., Y. Tachikawa, and K. Takara, 2006: Input data resolution analysis for distributed hydrological modeling. J. Hydrol., 319, 36-50, doi:10.1016/j.jhydrol.2005.04.025.

$\longrightarrow,-$, and — 2007: Selection of scale for distributed hydrological modelling in ungauged basins. Predictions in Ungauged Basins: PUB Kick-off (Proceedings of the PUB Kick-off meeting held in Brasilia, 20-22 November 2002), 290-297.

Skamarock, W. C., and Coauthors, 2008: A Description of the Advanced Research WRF Version 3. Boulder, Colorado, USA,

Steele-Dunne, S., P. Lynch, R. McGrath, T. Semmler, S. Wang, J. Hanafin, and P. Nolan, 2008: The impacts of climate change on hydrology in Ireland. J. Hydrol., 356, 28-45, doi:10.1016/j.jhydrol.2008.03.025.

Stewart, I. T., D. R. Cayan, and M. D. Dettinger, 2005: Changes toward earlier streamflow timing across western North America. J. Clim., 18, 1136-1155, doi:10.1175/JCLI3321.1.

Suklitsch, M., A. Gobiet, A. Leuprecht, and C. Frei, 2008: High Resolution Sensitivity Studies with the Regional Climate Model CCLM in the Alpine Region. Meteorol. Zeitschrift, 17, 
467-476, doi:10.1127/0941-2948/2008/0308.

Surfleet, C. G., and D. Tullos, 2013: Uncertainty in hydrologic modelling for estimating hydrologic response due to climate change (Santiam River, Oregon). Hydrol. Process., 27, 3560-3576, doi:10.1002/hyp.9485.

— D. Tullos, H. Chang, and I.-W. Jung, 2012: Selection of hydrologic modeling approaches for climate change assessment: A comparison of model scale and structures. J. Hydrol., 464-465, 233-248, doi:10.1016/j.jhydrol.2012.07.012.

Teutschbein, C., and J. Seibert, 2010: Regional climate models for hydrological impact studies at the catchment scale: A review of recent modeling strategies. Geogr. Compass, 4, 834-860, doi:10.1111/j.1749-8198.2010.00357.x.

Thiessen, A. H., 1911: Precipitation Averages for Large Areas. Mon. Weather Rev., 39, 10821089, doi:10.1175/1520-0493(1911)39<1082b:PAFLA>2.0.CO;2.

Thompson, G., P. R. Field, R. M. Rasmussen, and W. D. Hall, 2008: Explicit Forecasts of Winter Precipitation Using an Improved Bulk Microphysics Scheme. Part II: Implementation of a New Snow Parameterization. Mon. Weather Rev., 136, 5095-5115, doi:10.1175/2008MWR2387.1.

Tramblay, Y., C. Bouvier, P.-A. Ayral, and A. Marchandise, 2011: Impact of rainfall spatial distribution on rainfall-runoff modelling efficiency and initial soil moisture conditions estimation. Nat. Hazards Earth Syst. Sci., 11, 157-170, doi:10.5194/nhess-11-157-2011.

USDA (U.S. Department of Agriculture), 1992: Forest Land Distribution Data for the United States.

—, 1994: State Soil Geographic (STATSGO) Database - Data Use Information. Misc. Pub. $107 \mathrm{pp}$.

Vano, J. A., and D. P. Lettenmaier, 2014: A sensitivity-based approach to evaluating future changes in Colorado River discharge. Clim. Change, 122, 621-634, doi:10.1007/s10584013-1023-x.

— - T. Das, and D. P. Lettenmaier, 2012: Hydrologic Sensitivities of Colorado River Runoff to Changes in Precipitation and Temperature. J. Hydrometeorol., 13, 932-949, doi:10.1175/JHM-D-11-069.1.

Velázquez, J. A., and Coauthors, 2013: An ensemble approach to assess hydrological models' contribution to uncertainties in the analysis of climate change impact on water resources. Hydrol. Earth Syst. Sci., 17, 565-578, doi:10.5194/hess-17-565-2013.

Verseghy, D., 1991: CLASS—A Canadian land surface scheme for GCMs. I. Soil model. Int. J. Climatol., 11, 111-133. 
Vicuña, S., R. D. Garreaud, and J. McPhee, 2011: Climate change impacts on the hydrology of a snowmelt driven basin in semiarid Chile. Clim. Change, 105, 469-488, doi:10.1007/s10584-010-9888-4.

Wagener, T., K. van Werkhoven, P. Reed, and Y. Tang, 2009: Multiobjective sensitivity analysis to understand the information content in streamflow observations for distributed watershed modeling. Water Resour. Res., 45, W02501, doi:10.1029/2008WR007347.

Wayand, N. E., A. F. Hamlet, M. Hughes, S. I. Feld, and J. D. Lundquist, 2013: Intercomparison of Meteorological Forcing Data from Empirical and Mesoscale Model Sources in the North Fork American River Basin in Northern Sierra Nevada, California. J. Hydrometeorol., 14, 677-699, doi:10.1175/JHM-D-12-0102.1.

van Werkhoven, K., T. Wagener, P. Reed, and Y. Tang, 2008: Characterization of watershed model behavior across a hydroclimatic gradient. Water Resour. Res., 44, 1-16, doi:10.1029/2007WR006271.

,,--- , and -2009 : Sensitivity-guided reduction of parametric dimensionality for multi-objective calibration of watershed models. Adv. Water Resour., 32, 1154-1169, doi:10.1016/j.advwatres.2009.03.002.

Wi, S., F. Dominguez, M. Durcik, J. Valdes, H. F. Diaz, and C. L. Castro, 2012: Climate change projection of snowfall in the Colorado River Basin using dynamical downscaling. Water Resour. Res., 48, W05504, doi:10.1029/2011WR010674.

Wilby, R. L., 2005: Uncertainty in water resource model parameters used for climate change impact assessment. Hydrol. Process., 19, 3201-3219, doi:10.1002/hyp.5819.

Wood, A., L. Leung, V. Sridhar, and D. Lettenmaier, 2004: Hydrologic implications of dynamical and statistical approaches to downscaling climate model outputs. Clim. Change, 62, 189-216.

Wood, E. F., D. P. Lettenmaier, and V. G. Zartarian, 1992: A Land-Surface Hydrology Parameterization With Subgrid Variability for General Circulation Models. J. Geophys. Res., 97, 2717-2728, doi:10.1029/91JD01786.

Xu, C., 1999: From GCMs to river flow: a review of downscaling methods and hydrologic modelling approaches. Prog. Phys. Geogr., 23, 229-249, doi:10.1177/030913339902300204.

Yang, Z.-L., and Coauthors, 2011: The community Noah land surface model with multiparameterization options (Noah-MP): 2. Evaluation over global river basins. $J$. Geophys. Res., 116, 1-16, doi:10.1029/2010JD015140.

Yilmaz, K. K., H. V. Gupta, and T. Wagener, 2008: A process-based diagnostic approach to 
model evaluation: Application to the NWS distributed hydrologic model. Water Resour. Res., 44, W09417, doi:10.1029/2007WR006716.

Zhao, G., G. Hörmann, N. Fohrer, and J. Gao, 2009: Impacts of spatial data resolution on simulated discharge, a case study of Xitiaoxi catchment in South China. Adv. Geosci., 21, $131-137$. 


\section{List of Figures}

Figure 1: Location of the basins of interest: Yampa at Steamboat Springs $\left(1468 \mathrm{~km}^{2}\right)$, East at

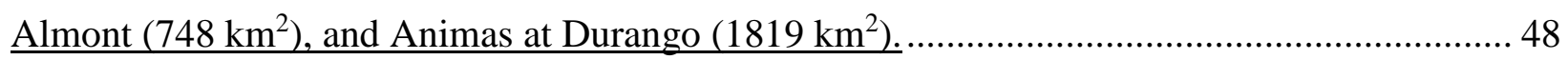

Figure 2: Basin-averaged observed ( $\mathrm{x}$ symbols) and simulated (colored lines) monthly precipitation values for current (CTRL, dashed lines) and future (PGW, solid lines) WRF outputs used in (a) experiment 1 (effects of WRF horizontal resolution) and (b) experiment 2 (effects of spatial aggregation), for period Oct/2002 - Sep/2008. Basin-averaged observed precipitation was estimated using neighboring SNOTEL stations, whose weights were assigned using the Thiessen interpolation method (Thiessen 1911).

Figure 3: Same as in Figure 2, but for basin-averaged monthly temperature. 50

Figure 4: Difference between simulated (CTRL) and observed (Obs) signature measures of hydrologic behavior (period Oct/2002 - Sep/2008) obtained from various hydrologic model structures (i.e. different symbols) and forcing datasets (i.e. different colors). Results are displayed for (a) experiment 1 (effects of WRF horizontal resolution) and (b) experiment 2 (effects of spatial aggregation)... 51

Figure 5: Impact of (a) WRF horizontal resolution (experiment 1) and (b) spatial aggregation of WRF 4-km resolution datasets on simulated hydrologic signature measures. Each column contains results for a specific metric, while different rows contain outputs from 12-km and 36km (y axis) versus model outputs using WRF datasets with $4 \mathrm{~km}$ horizontal grid space ( $\mathrm{x}$ axis). $\underline{\text { In each panel, different letters represent basins and different colors depict results from various }}$ hydrologic models (see legend for details). 52 
Figure 6: Partitioning of current (CTRL) and future (PGW) basin-averaged mean annual precipitation (diagonal, $\mathrm{mm} / \mathrm{year}$ ) into basin-averaged mean annual runoff (x axis, mm/year) and evapotranspiration (y axis, $\mathrm{mm} / \mathrm{year}$ ) obtained from various model structures (i.e. different symbols) and forcing datasets (i.e. different colors) for the period Oct/2002 - Sep/2008. Results are displayed for (a) experiment 1 (effects of WRF horizontal resolution) and (b) experiment 2 (effects of spatial forcing aggregation). 53

Figure 7: Projected changes in basin-averaged mean annual runoff ( $\mathrm{x}$ axis, mm/year) and evapotranspiration (y axis, $\mathrm{mm} / \mathrm{year}$ ) obtained from various model structures (i.e. different symbols) and forcing datasets (i.e. different colors) for the period Oct/2002 - Sep/2008. Results are displayed for (a) experiment 1 (effects of WRF horizontal resolution) and (b) experiment 2 (effects of spatial forcing aggregation). 54

Figure 8: Difference between future (PGW) and current (CTRL) simulated signature measures of hydrologic behavior, obtained from various hydrologic model structures (i.e. different symbols) and forcing datasets (i.e. different colors) over a six-average water year (Oct/2002 - Sep/2008). Results are displayed for (a) experiment 1 (effects of WRF horizontal resolution) and (b) experiment 2 (effects of spatial forcing aggregation). 55 
Table 1: Three study watersheds' characteristics. Hydrologic variables correspond to the period Oct/2000-Sep/2008. P, R, PE, RE and DI denote basin-averaged mean annual values of precipitation, runoff, potential evapotranspiration, runoff efficiency (R/P) and dryness index $(\mathrm{PE} / \mathrm{P})$, respectively.

\begin{tabular}{|c|c|c|c|c|c|c|c|c|}
\hline Location & $\begin{array}{l}\text { USGS } \\
\text { ID }\end{array}$ & $\begin{array}{l}\text { Area } \\
\left(\mathrm{km}^{2}\right)\end{array}$ & $\begin{array}{l}\text { Mean } \\
\text { basin } \\
\text { elevation } \\
\text { (m.a.s.l.) }\end{array}$ & $\begin{array}{l}\text { Mean } \\
\text { annual } \\
\text { runoff } \\
(\mathrm{mm} / \mathrm{yr})\end{array}$ & $\begin{array}{c}\text { Mean } \\
\text { Precipitation } \\
\text { from WRF } \\
(\mathrm{mm} / \mathrm{yr})\end{array}$ & $\begin{array}{c}\text { Mean } \\
\text { annual } \\
\text { PE* }^{*} \\
(\mathrm{~mm} / \mathrm{yr})\end{array}$ & $\begin{array}{c}\text { Mean } \\
\text { annual } \\
\text { RE } \\
(\mathrm{R} / \mathrm{P})\end{array}$ & $\begin{array}{c}\text { Mean } \\
\text { annual } \\
\text { DI } \\
(\mathrm{PE} / \mathrm{P})\end{array}$ \\
\hline $\begin{array}{l}\text { Yampa at Steamboat } \\
\text { Springs }\end{array}$ & 09239500 & 1468 & 2674 & 228 & 717 & 953 & 0.32 & 1.33 \\
\hline East at Almont & 09112500 & 748 & 3127 & 327 & 782 & 757 & 0.42 & 0.97 \\
\hline Animas at Durango & 09361500 & 1819 & 3098 & 365 & 883 & 885 & 0.41 & 1.00 \\
\hline
\end{tabular}

*PE obtained from PRMS by using a Jensen-Haise formulation (Jensen et al. 1969) 
Table 2: Summary of data sources and simulation setup used in this study

\begin{tabular}{|c|c|c|c|c|}
\hline Model & Vegetation data & Soil data & Forcing variables* & $\begin{array}{c}\text { Spatial/temporal } \\
\text { discretization }\end{array}$ \\
\hline PRMS & $\begin{array}{l}\text { USGS 1-km gridded } \\
\text { vegetation type and } \\
\text { density data (USDA } \\
\text { 1992) }\end{array}$ & $\begin{array}{l}\text { State soils geographic } \\
\text { (STATSGO) 1-km } \\
\text { gridded soils data } \\
\text { (USDA 1994) }\end{array}$ & $\begin{array}{l}\text { Daily precipitation; } \\
\text { maximum and minimum } \\
\text { daily temperature. }\end{array}$ & $\begin{array}{l}4 \mathrm{~km} \text { and } \Delta \mathrm{t}=24 \\
\mathrm{~h}\end{array}$ \\
\hline VIC & $\begin{array}{l}\text { UMD 1-km Global } \\
\text { Land Cover } \\
\text { Classification (Hansen } \\
\text { et al. 2000) }\end{array}$ & $\begin{array}{l}\text { State soils geographic } \\
\text { (STATSGO) } 1-\mathrm{km} \\
\text { gridded soils data } \\
\text { (USDA 1994) }\end{array}$ & $\begin{array}{l}\text { Precipitation, } \\
\text { temperature, shortwave } \\
\text { and longwave radiation, } \\
\text { wind speed, relative } \\
\text { humidity and air } \\
\text { pressure. }\end{array}$ & $4 \mathrm{~km}$ and $\Delta \mathrm{t}=1 \mathrm{~h}$ \\
\hline $\begin{array}{l}\text { Noah-LSM } \\
\text { and } \\
\text { Noah-MP }\end{array}$ & $\begin{array}{l}\text { National Land Cover } \\
\text { Data Base, } 2006 \text { (Fry } \\
\text { et al. 2011). }\end{array}$ & $\begin{array}{l}\text { State soils geographic } \\
\text { (STATSGO) } 1-\mathrm{km} \\
\text { gridded soils data } \\
\text { (USDA 1994) }\end{array}$ & $\begin{array}{l}\text { Precipitation, } \\
\text { temperature, shortwave } \\
\text { and longwave radiation, } \\
\text { wind speed, relative } \\
\text { humidity and air } \\
\text { pressure. }\end{array}$ & $4 \mathrm{~km}$ and $\Delta \mathrm{t}=1 \mathrm{~h}$ \\
\hline
\end{tabular}

*Air temperature at $2 \mathrm{~m}$ and wind speed at $10 \mathrm{~m}$ are used for hydrologic simulations. 
Table 3: Overview of hydrologic model components used in this study

\begin{tabular}{|c|c|c|c|c|}
\hline Model & $\begin{array}{c}\text { Snow accumulation } \\
\text { and melt }\end{array}$ & $\begin{array}{l}\text { Canopy } \\
\text { storage }\end{array}$ & $\begin{array}{l}\text { Moisture in the soil } \\
\text { column/surface runoff }\end{array}$ & Baseflow \\
\hline PRMS & $\begin{array}{l}\text { 2-layer energy/mass } \\
\text { balance model. Snowpack } \\
\text { energy balance is } \\
\text { computed every } 12 \text { hours. }\end{array}$ & $\begin{array}{l}\text { Precipitation can be intercepted by and evaporated } \\
\text { from the plant canopy. Precipitation that is not } \\
\text { intercepted by the canopy layer (throughfall) is } \\
\text { distributed to the watershed land surface. Interception } \\
\text { of precipitation by the plant canopy is computed } \\
\text { during a time step as a function of plant-cover density } \\
\text { and the storage available on the predominant plant- } \\
\text { cover type in each HRU. }\end{array}$ & $\begin{array}{l}\text { Surface runoff and } \\
\text { infiltration are computed } \\
\text { using a non-linear variable- } \\
\text { source-area method } \\
\text { allowing for cascade flow. }\end{array}$ & $\begin{array}{l}\text { The groundwater zone is } \\
\text { conceptualized as a linear } \\
\text { reservoir (ie. baseflow is } \\
\text { computed as a linear } \\
\text { function of groundwater } \\
\text { storage). }\end{array}$ \\
\hline VIC & $\begin{array}{l}\text { 2-layer energy/mass } \\
\text { balance model. }\end{array}$ & $\begin{array}{l}\text { Water enters 1-layer canopy reservoir, and can leave } \\
\text { as canopy evaporation, transpiration or throughfall. } \\
\text { Canopy throughfall occurs when additional } \\
\text { precipitation exceeds the storage capacity of the } \\
\text { canopy. Different vegetation classes are allowed } \\
\text { within a unique grid cell via a 'mosaic' approach, } \\
\text { where energy and water balance terms are computed } \\
\text { independently for each coverage class (vegetation and } \\
\text { bare soil). }\end{array}$ & $\begin{array}{l}\text { An infiltration capacity } \\
\text { function is defined. Vertical } \\
\text { movement of moisture } \\
\text { through soil follows 1-D } \\
\text { Richards equation. }\end{array}$ & $\begin{array}{l}\text { Defined as a function of the } \\
\text { soil moisture in the third } \\
\text { layer (Arno formulation). } \\
\text { The function is linear } \\
\text { below a soil moisture } \\
\text { threshold, and becomes } \\
\text { nonlinear above that } \\
\text { threshold. }\end{array}$ \\
\hline Noah-LSM & $\begin{array}{l}\text { 1-layer energy/mass } \\
\text { balance model that } \\
\text { simulates snow } \\
\text { accumulation, } \\
\text { sublimation, melting and } \\
\text { heat exchange at snow- } \\
\text { atmosphere and snow-soil } \\
\text { interfaces. }\end{array}$ & $\begin{array}{l}\text { One canopy layer, simple canopy resistance. Simple } \\
\text { Jarvis type of canopy resistance function, single } \\
\text { linearized energy balance equation representing } \\
\text { combined ground/vegetation surface, considering } \\
\text { seasonal LAI and green vegetation fraction. }\end{array}$ & $\begin{array}{l}\text { Surface runoff is computed } \\
\text { as the difference between } \\
\text { throughfall and a maximum } \\
\text { infiltration rate. Vertical } \\
\text { movement of moisture } \\
\text { through soil layers follows } \\
\text { 1-D Richards equation. }\end{array}$ & $\begin{array}{l}\text { Computed as the product } \\
\text { of a scaling factor between } \\
0 \text { and } 1 \text { and the hydraulic } \\
\text { conductivity of the bottom } \\
\text { layer. }\end{array}$ \\
\hline Noah-MP & $\begin{array}{l}3 \text {-layer energy/mass } \\
\text { balance model that } \\
\text { represents percolation, } \\
\text { retention and refreezing } \\
\text { of meltwater within the } \\
\text { snowpack. }\end{array}$ & $\begin{array}{l}\text { Snow interception includes loading/unloading, } \\
\text { melt/refreeze capabilities, and sublimation of canopy- } \\
\text { intercepted snow, along with detailed representation of } \\
\text { transmission and attenuation of radiation through the } \\
\text { canopy, within- and below-canopy turbulence, and } \\
\text { different options to represent the biophysical controls } \\
\text { on transpiration. }\end{array}$ & $\begin{array}{l}\text { Surface runoff is an } \\
\text { exponential function of } \\
\text { depth to water table. } \\
\text { Vertical movement of } \\
\text { moisture through soil layers } \\
\text { follows 1-D Richards } \\
\text { equation. }\end{array}$ & $\begin{array}{l}\text { Baseflow is parameterized } \\
\text { as an exponential decaying } \\
\text { function of the water table } \\
\text { level (SIMTOP). }\end{array}$ \\
\hline
\end{tabular}


Table 4: Signature measures used to evaluate model performance and projected changes in catchment behavior

\begin{tabular}{clll}
\hline Notation & \multicolumn{1}{c}{ Short description } & \multicolumn{1}{c}{ Equation } & \multicolumn{1}{c}{ Hydrologic process } \\
\hline RR & Runoff Ratio & $R R=R / P$ & Overall water balance (ET processes). \\
CTR & Center Time of Runoff & $C T R=\frac{\sum_{i=1}^{N} t_{i} Q_{i}}{\sum_{i=1}^{N} Q_{i}}$ & Seasonality of runoff. \\
FMS & FDC Mid-segment Slope & $F M S=\frac{\log \left(Q_{m 1}\right)-\log \left(Q_{m 2}\right)}{m_{1}-m_{2}}$ & $\begin{array}{l}\text { Variability, or flashiness, of the flow } \\
\text { magnitudes. }\end{array}$ \\
FLV & $\begin{array}{l}\text { FDC Low-segment } \\
\text { Volume }\end{array}$ & $F L V=\sum_{l=1}^{L}\left[\log \left(Q_{l}\right)-\log \left(Q_{L}\right)\right]$ & $\begin{array}{l}\text { Measure of the long-term baseflow } \\
\text { processes. }\end{array}$ \\
\hline
\end{tabular}

$R$ : basin-averaged mean annual runoff.

$P$ : basin-averaged mean annual precipitation.

$Q_{m 1}$ : flow with exceedance probability of $\mathrm{m}_{1}=0.2$.

$Q_{m 2}$ : flow with exceedance probability of $\mathrm{m}_{2}=0.7$.

$l=1,2, \ldots, L$ is the index into the array of flow values located within the low-flow segment $(0.7$ -

1.0 exceedance probabilities), being $L$ the index for minimum flow.

$N$ : total number of days in a water year. 
Table 5: Sample standard deviation in the error of simulated signature measures (CTRL - Obs) computed from hydrologic multi-model ensemble outputs obtained with different forcing datasets. RR, CTR, FMS and FLV denote runoff ratio, center of time of runoff, flow duration curve mid-segment slope, and flow duration curve low-flow volumes, respectively.

\begin{tabular}{lcccccc}
\hline \multirow{2}{*}{ ignature } & \multicolumn{2}{c}{ Yampa } & \multicolumn{2}{c}{ East } & \multicolumn{2}{c}{ Animas } \\
\cline { 2 - 7 } & Experiment 1 & Experiment 2 & Experiment 1 & Experiment 2 & Experiment 1 & Experiment 2 \\
\hline RR & & & & & & \\
$4 \mathrm{~km}$ & 0.02 & & 0.03 & & 0.04 & \\
$12 \mathrm{~km}$ & 0.06 & 0.03 & 0.03 & 0.04 & 0.06 & 0.02 \\
$36 \mathrm{~km}$ & 0.06 & 0.04 & 0.07 & 0.01 & 0.08 & 0.01 \\
\hline CTR (days since Oct. 1) & & & & & \\
$4 \mathrm{~km}$ & 2.32 & & 5.96 & & 3.60 & \\
$12 \mathrm{~km}$ & 9.37 & 4.25 & 7.99 & 7.88 & 6.96 & 4.35 \\
$36 \mathrm{~km}$ & 18.54 & 6.29 & 8.31 & 10.46 & 7.50 & 7.22 \\
\hline FMS $\left(\log \left(\mathrm{m}^{3} / \mathrm{s}\right)\right)$ & & & & & \\
$4 \mathrm{~km}$ & 0.65 & & 0.31 & & 0.07 & \\
$12 \mathrm{~km}$ & 1.45 & 0.92 & 0.58 & 0.41 & 0.14 & 0.05 \\
$36 \mathrm{~km}$ & 1.81 & 1.50 & 0.43 & 0.55 & 0.24 & 0.08 \\
\hline FLV $\left(\log \left(\mathrm{m}^{3} / \mathrm{s}\right)\right)$ & & & & & \\
$4 \mathrm{~km}$ & 172.54 & & 73.81 & & 47.44 & \\
$12 \mathrm{~km}$ & 296.98 & 267.63 & 122.76 & 78.59 & 100.06 & 47.87 \\
$36 \mathrm{~km}$ & 2238.45 & 285.34 & 145.06 & 87.10 & 122.86 & 46.62 \\
\hline \multicolumn{7}{l}{} \\
\hline
\end{tabular}


Table 6: Sample standard deviation (mm/year) in the partitioning of mean annual precipitation into mean annual runoff and mean annual ET, computed from hydrologic multi-model ensemble outputs obtained with different forcing datasets. Larger numbers indicate that a large spread in precipitation partitioning is introduced by the choice of hydrologic model.

\begin{tabular}{lcccccc}
\hline \multirow{2}{*}{ Forcing data } & \multicolumn{2}{c}{ Yampa } & \multicolumn{2}{c}{ East } & \multicolumn{2}{c}{ Animas } \\
\cline { 2 - 7 } & Experiment 1 & Experiment 2 & Experiment 1 & Experiment 2 & Experiment 1 & Experiment 2 \\
\hline Current climate (CTRL) & & & & & & \\
$4 \mathrm{~km}$ & 26.4 & & 40.7 & & 55.4 & \\
$12 \mathrm{~km}$ & 47.8 & 33.0 & 37.4 & 45.5 & 65.2 & 36.2 \\
$36 \mathrm{~km}$ & 41.3 & 51.7 & 59.1 & 20.1 & 77.2 & 23.4 \\
Future climate (PGW) & & & & & \\
$4 \mathrm{~km}$ & 48.5 & & 31.5 & & 53.0 & \\
$12 \mathrm{~km}$ & 63.6 & 57.7 & 47.2 & 32.4 & 75.6 & 37.1 \\
$36 \mathrm{~km}$ & 50.0 & 76.4 & 85.3 & 44.5 & 85.1 & 21.0 \\
\hline
\end{tabular}


Table 7: Sample standard deviation ( $\mathrm{mm} /$ year) in projected changes in mean annual runoff and mean annual ET, computed from (a) multiple hydrologic model structures and a single forcing dataset, and (b) multiple forcing datasets and a single hydrologic model structure. Larger numbers indicate that a large spread in projected changes is introduced by the choice of hydrologic model or forcing dataset.

\begin{tabular}{lcccccc}
\hline \multirow{2}{*}{ Experiment } & \multicolumn{2}{c}{ Yampa } & \multicolumn{2}{c}{ East } & \multicolumn{2}{c}{ Animas } \\
\cline { 2 - 7 } & Experiment 1 & Experiment 2 & Experiment 1 & Experiment 2 & Experiment 1 & Experiment 2 \\
\hline \multicolumn{2}{l}{ (a) Fixed forcing dataset } & & & & & \\
$4 \mathrm{~km}$ & 23.9 & & 23.3 & & 8.8 & \\
$12 \mathrm{~km}$ & 20.5 & 26.5 & 16.7 & 25.1 & 15.2 & 12.6 \\
$36 \mathrm{~km}$ & 12.9 & 30.5 & 31.5 & 27.5 & 12.8 & 17.8 \\
(b) Fixed hydrologic model & & & & & \\
PRMS & 12.4 & 1.2 & 28.5 & 7.4 & 27.4 & 10.5 \\
VIC & 10.0 & 4.8 & 23.1 & 8.2 & 30.2 & 5.1 \\
Noah-LSM & 15.9 & 6.1 & 14.9 & 2.3 & 20.2 & 5.1 \\
Noah-MP & 20.3 & 1.9 & 22.6 & 5.0 & 26.6 & 9.1 \\
\hline
\end{tabular}


Table 8: Sample standard deviation in projected changes (PGW - CTRL) in signature measures of catchment behavior, computed from hydrologic multi-model ensemble outputs obtained with different forcing datasets. RR, CTR, FMS and FLV denote runoff ratio, center of time of runoff, flow duration curve mid-segment slope, and flow duration curve low-flow volumes, respectively.

\begin{tabular}{lcccccc}
\hline Signature & \multicolumn{2}{c}{ Yampa } & \multicolumn{2}{c}{ East } & \multicolumn{2}{c}{ Animas } \\
\cline { 2 - 7 } & Experiment 1 & Experiment 2 & Experiment 1 & Experiment 2 & Experiment 1 & Experiment 2 \\
\hline RR & & & & & & \\
$4 \mathrm{~km}$ & 0.02 & & 0.02 & & 0.01 & \\
$12 \mathrm{~km}$ & 0.03 & 0.03 & 0.02 & 0.02 & 0.02 & 0.01 \\
$36 \mathrm{~km}$ & 0.02 & 0.03 & 0.03 & 0.02 & 0.01 & 0.01 \\
\hline CTR (days since Oct. 1) & & & & & \\
$4 \mathrm{~km}$ & 4.10 & & 2.90 & & 3.25 & \\
$12 \mathrm{~km}$ & 2.29 & 4.54 & 1.73 & 2.71 & 3.29 & 3.11 \\
$36 \mathrm{~km}$ & 1.65 & 4.20 & 3.38 & 2.95 & 2.01 & 2.28 \\
\hline FMS $\left(\log \left(\mathrm{m}^{3} / \mathrm{s}\right)\right)$ & & & & & \\
$4 \mathrm{~km}$ & 0.24 & & 0.19 & & 0.11 & \\
$12 \mathrm{~km}$ & 0.17 & 0.22 & 0.17 & 0.19 & 0.23 & 0.10 \\
$36 \mathrm{~km}$ & 0.12 & 0.44 & 0.17 & 0.19 & 0.16 & 0.08 \\
\hline FLV $\left(\log \left(\mathrm{m}^{3} / \mathrm{s}\right)\right)$ & & & & & \\
$4 \mathrm{~km}$ & 268.65 & & 21.40 & & 50.33 & \\
$12 \mathrm{~km}$ & 150.66 & 170.56 & 53.93 & 31.58 & 45.50 & 54.55 \\
$36 \mathrm{~km}$ & 401.64 & 85.76 & 101.33 & 45.96 & 63.04 & 47.15 \\
\hline
\end{tabular}




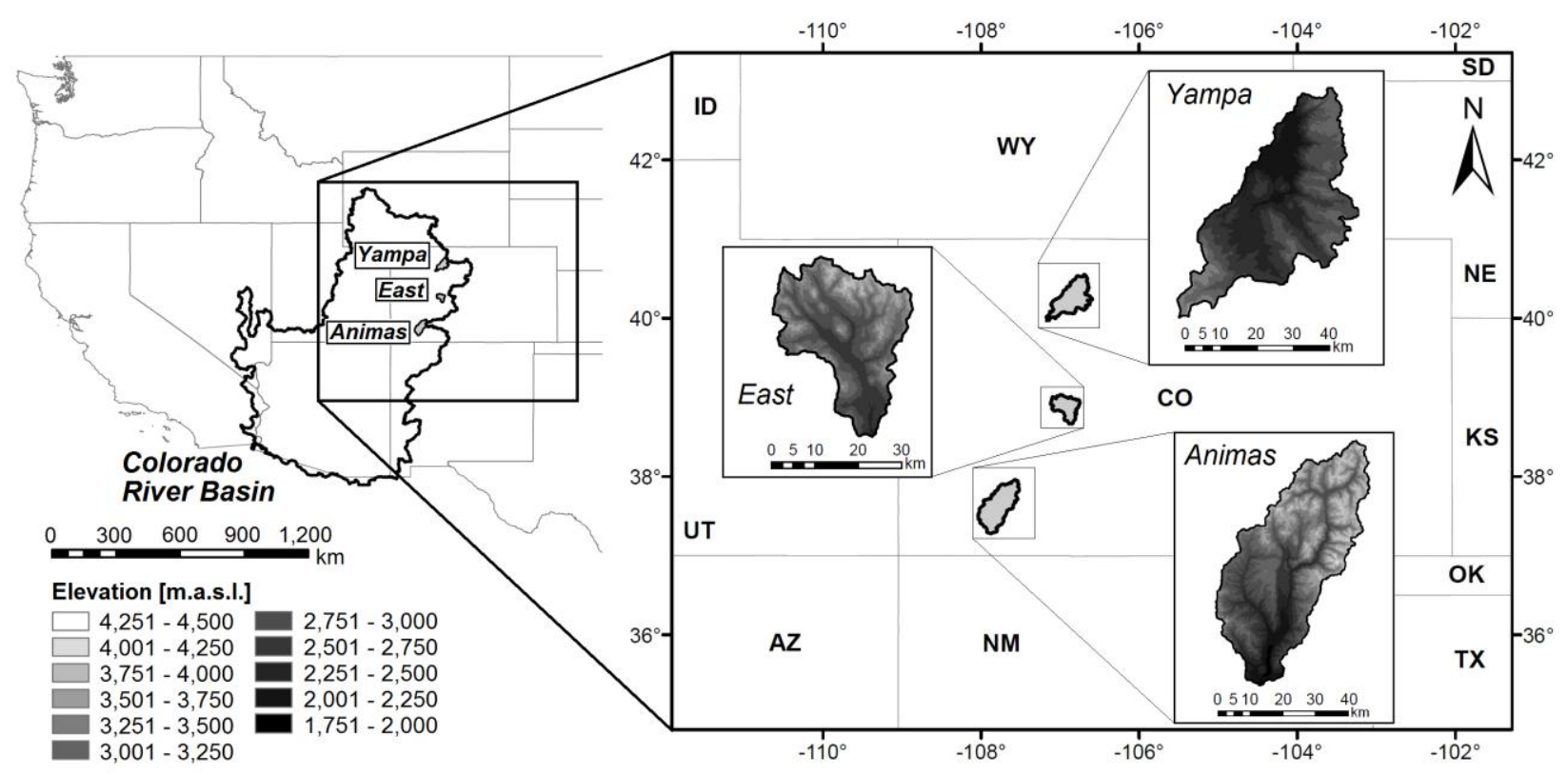

Figure 1: Location of the basins of interest: Yampa at Steamboat Springs $\left(1468 \mathrm{~km}^{2}\right)$, East at Almont $\left(748 \mathrm{~km}^{2}\right)$, and Animas at Durango $\left(1819 \mathrm{~km}^{2}\right)$. 
(a) Experiment 1: effects of WRF horizontal resolution
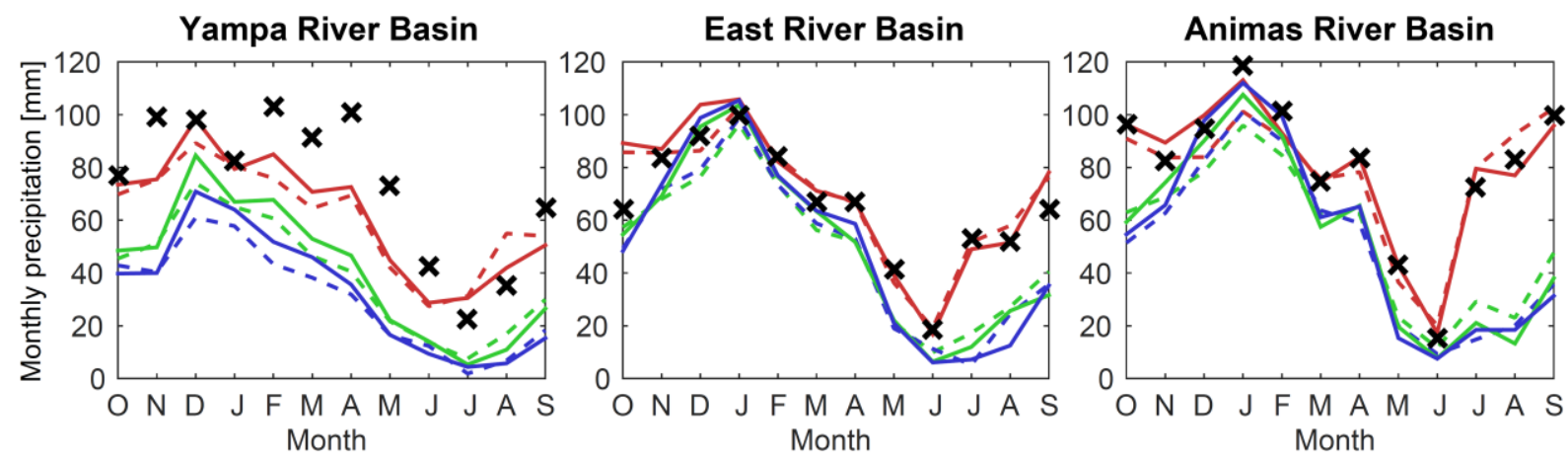

$-4 \mathrm{~km}-12 \mathrm{~km}-36 \mathrm{~km} \quad \times$ Obs

(b) Experiment 2: effects of spatial aggregation

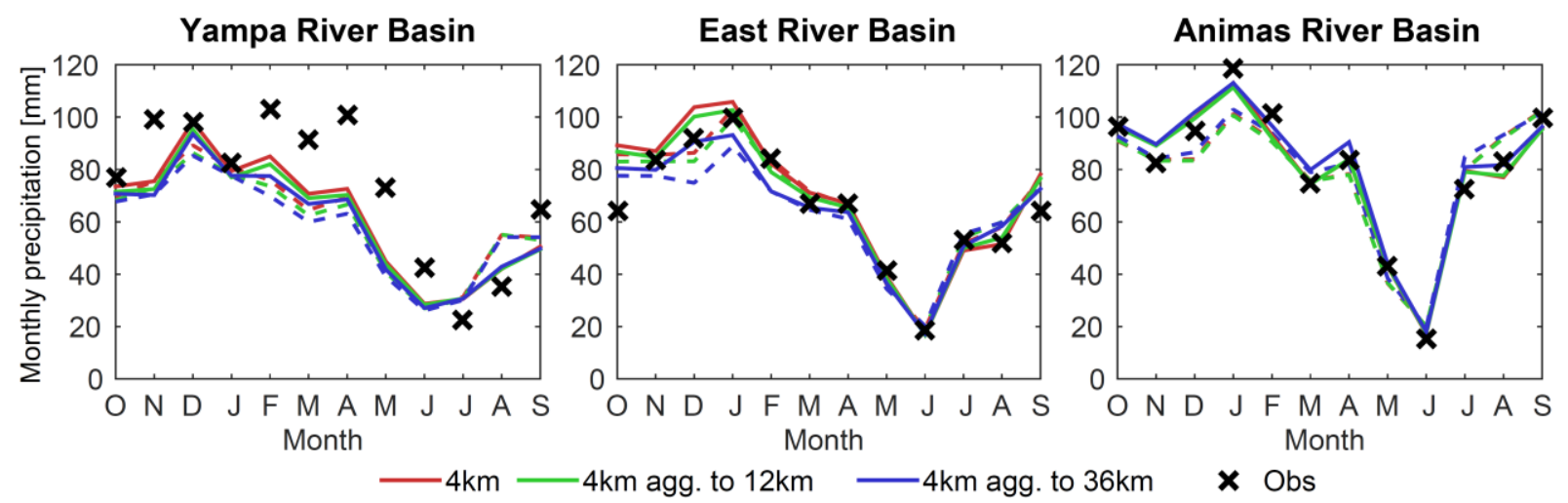

Figure 2: Basin-averaged observed ( $\mathrm{x}$ symbols) and simulated (colored lines) monthly precipitation values for current (CTRL, dashed lines) and future (PGW, solid lines) WRF outputs used in (a) experiment 1 (effects of WRF horizontal resolution) and (b) experiment 2 (effects of spatial aggregation), for period Oct/2002 - Sep/2008. Basin-averaged observed precipitation was estimated using neighboring SNOTEL stations, whose weights were assigned using the Thiessen interpolation method (Thiessen 1911). 
(a) Experiment 1: effects of WRF horizontal resolution
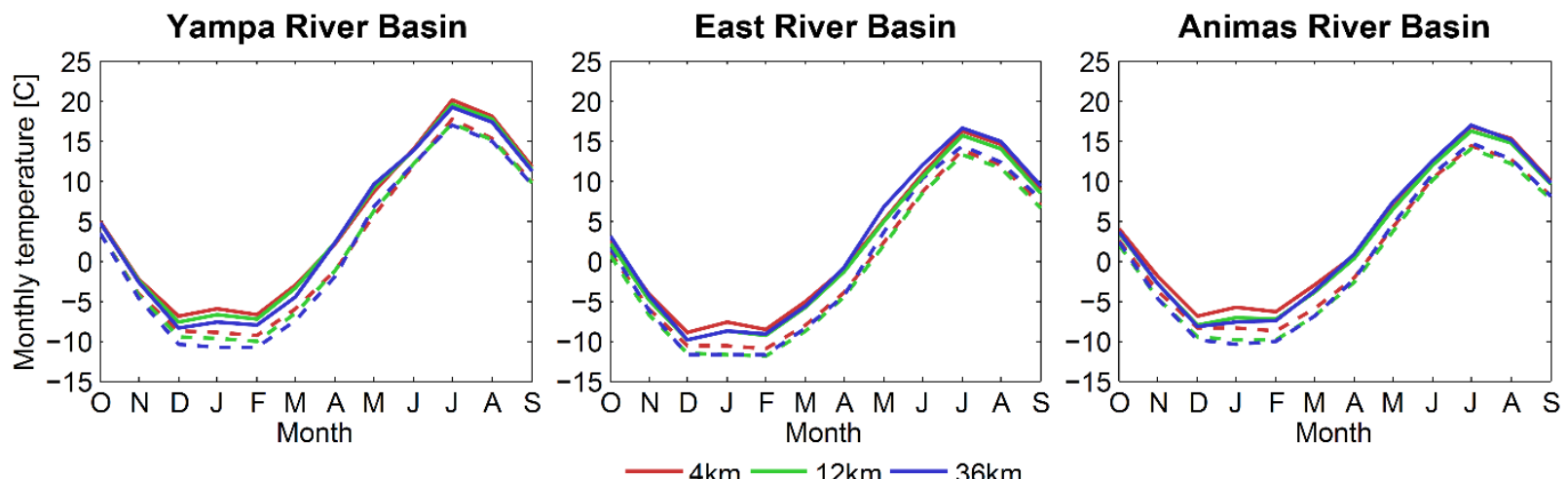

(b) Experiment 2: effects of spatial aggregation
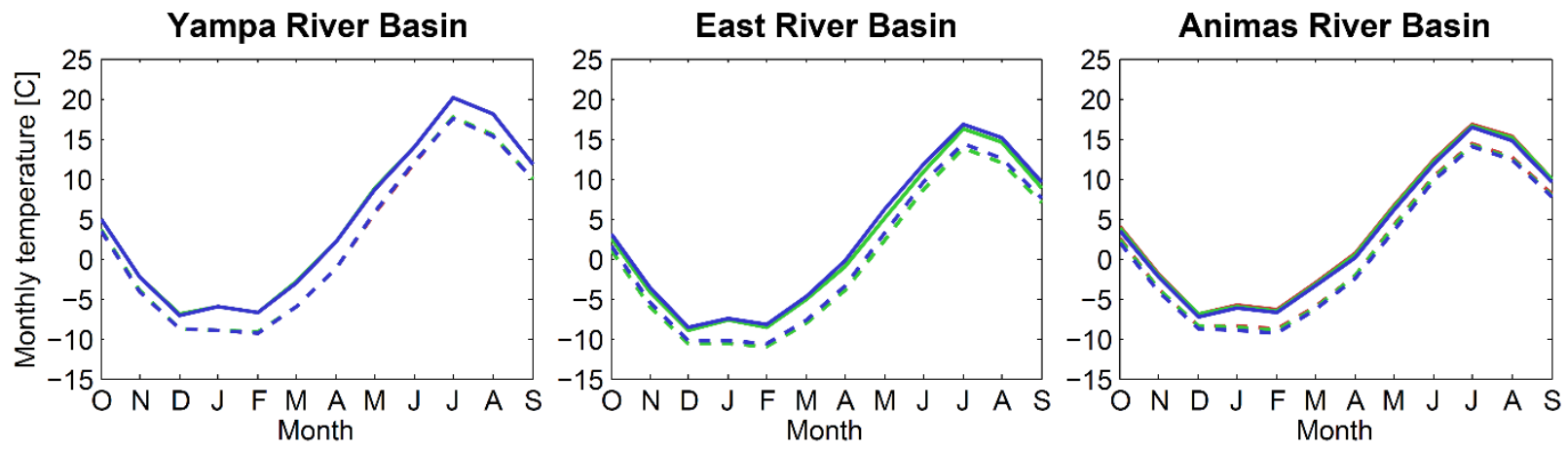

$-4 \mathrm{~km}=4 \mathrm{~km}$ agg. to $12 \mathrm{~km}-4 \mathrm{~km}$ agg. to $36 \mathrm{~km}$

Figure 3: Same as in Figure 2, but for basin-averaged monthly temperature. 
(a) Experiment 1
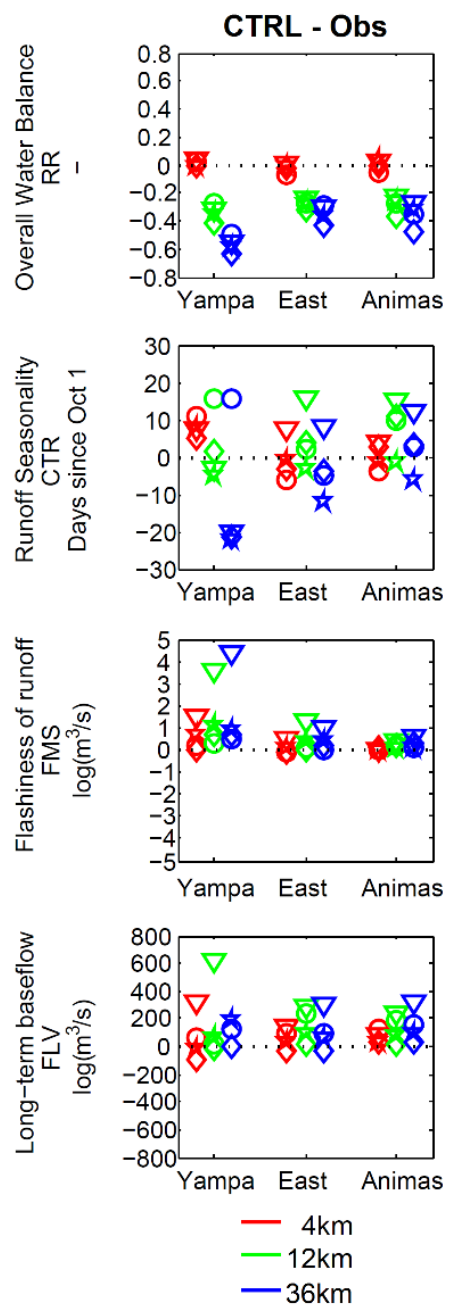

(b) Experiment 2
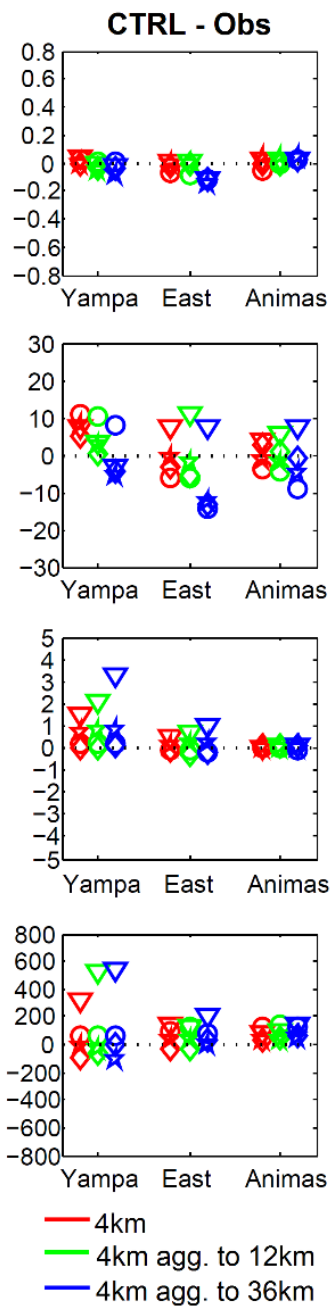

OPRMS $\nabla$ VIC $\diamond$ Noah-LSM ‡Noah-MP

Figure 4: Difference between simulated (CTRL) and observed (Obs) signature measures of hydrologic behavior (period Oct/2002 - Sep/2008) obtained from various hydrologic model structures (i.e. different symbols) and forcing datasets (i.e. different colors). Results are displayed for (a) experiment 1 (effects of WRF horizontal resolution) and (b) experiment 2 (effects of spatial aggregation). 
(a) Experiment 1: effects of WRF horizontal resolution
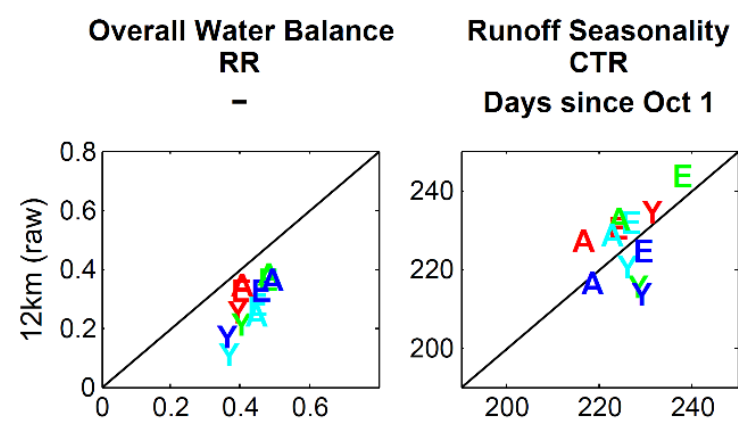
Flashiness of runoff FMS

Days since Oct 1
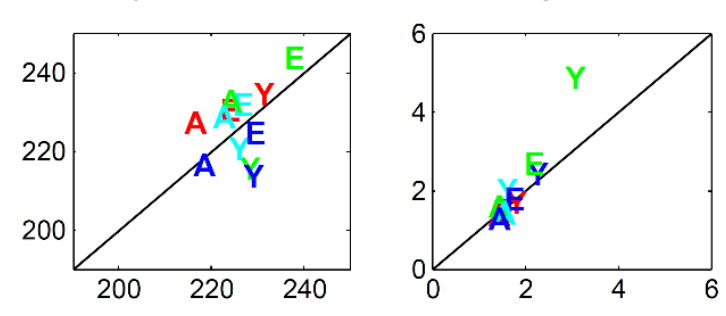
Long-term baseflow
FLV
$\log \left(\mathrm{m}^{3} / \mathrm{s}\right)$
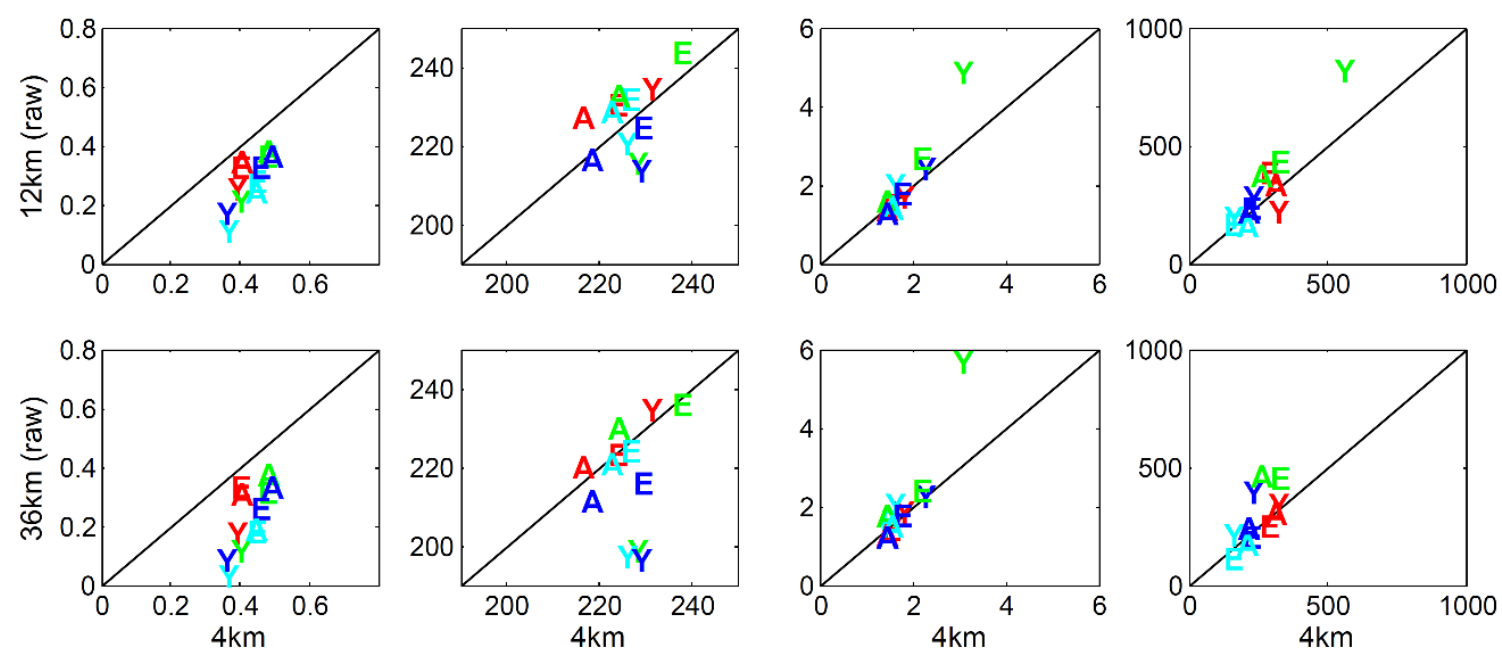

(b) Experiment 2: effects of spatial aggregation
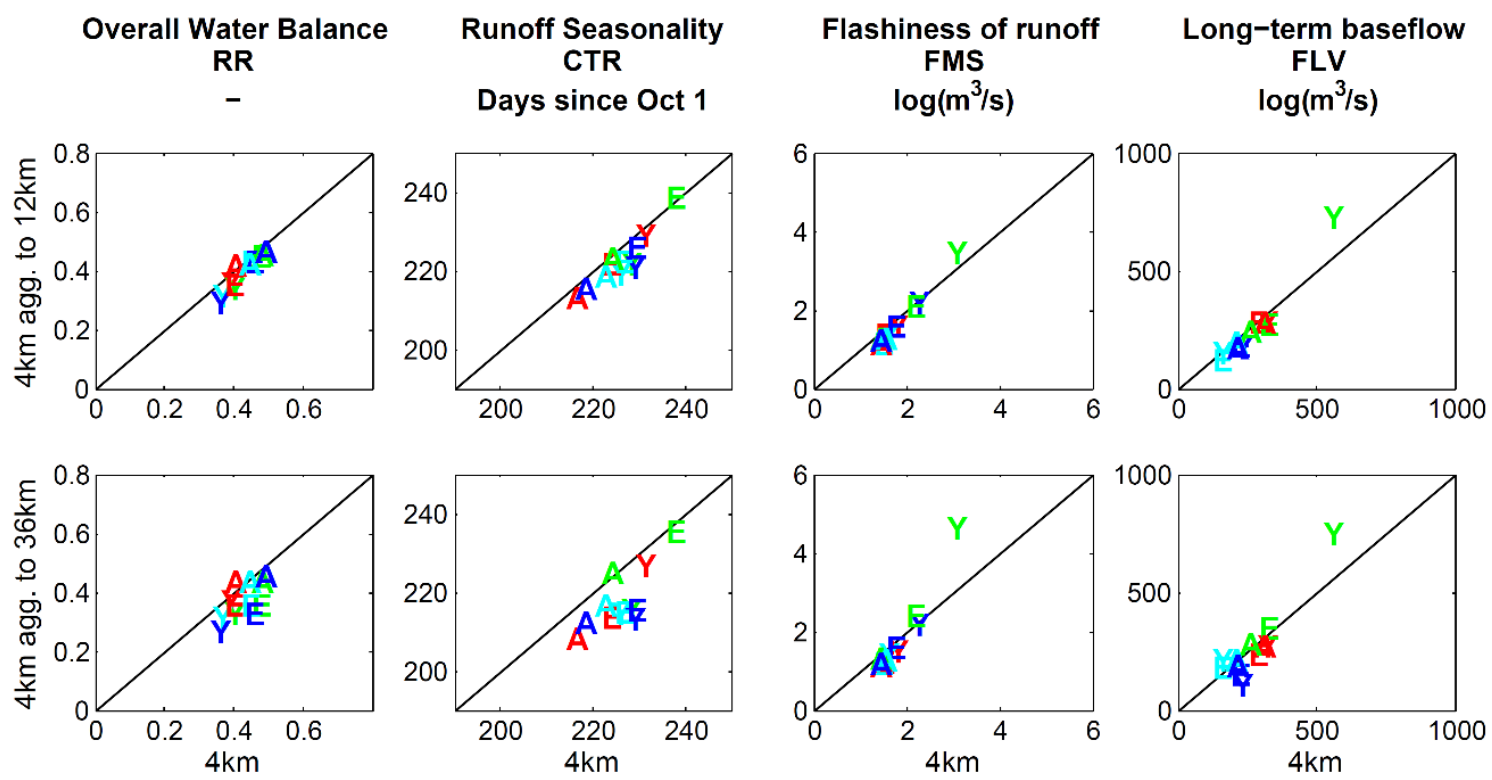

Y: Yampa River Basin

E: East River Basin

A: Animas River Basin

PRMS VIC Noah-LSM Noah-MP

Figure 5: Impact of (a) WRF horizontal resolution (experiment 1) and (b) spatial aggregation of WRF 4-km resolution datasets on simulated hydrologic signature measures. Each column contains results for a specific metric, while different rows contain outputs from 12-km and 36$\mathrm{km}$ (y axis) versus model outputs using WRF datasets with $4 \mathrm{~km}$ horizontal grid space (x axis). In each panel, different letters represent basins and different colors depict results from various hydrologic models (see legend for details). 
(a) Experiment 1: effects of WRF horizontal resolution

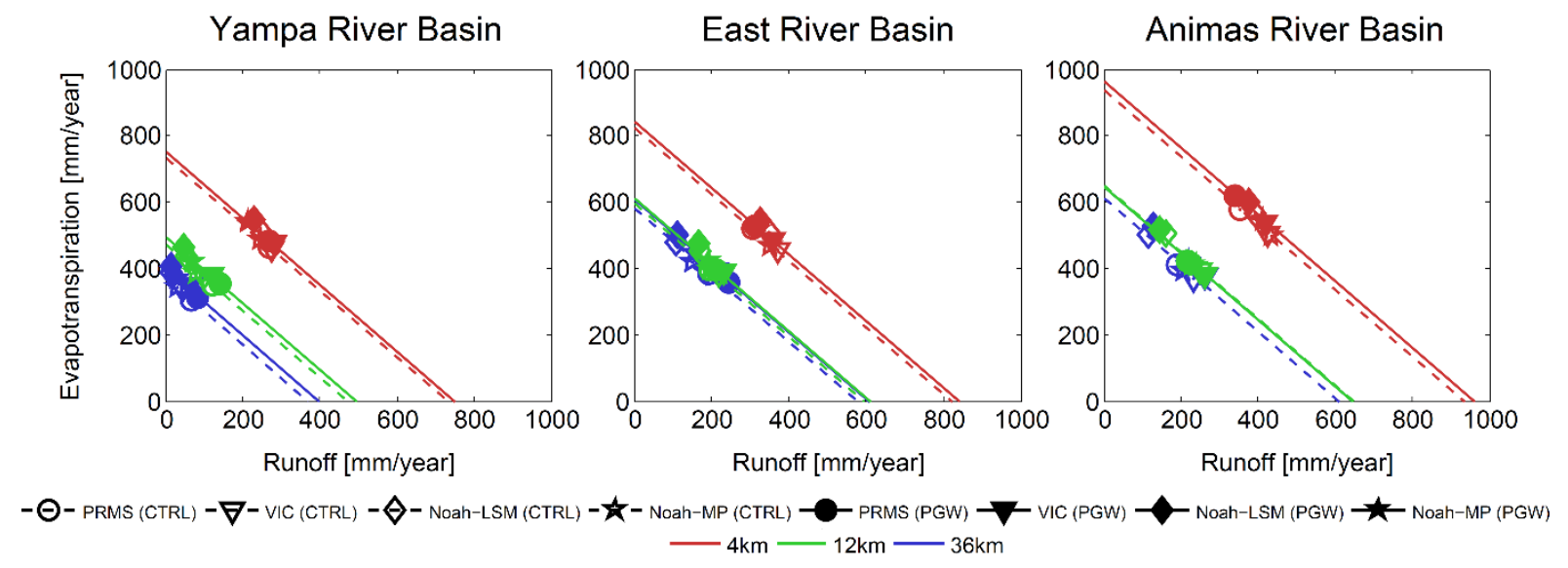

(b) Experiment 2: effects of spatial aggregation

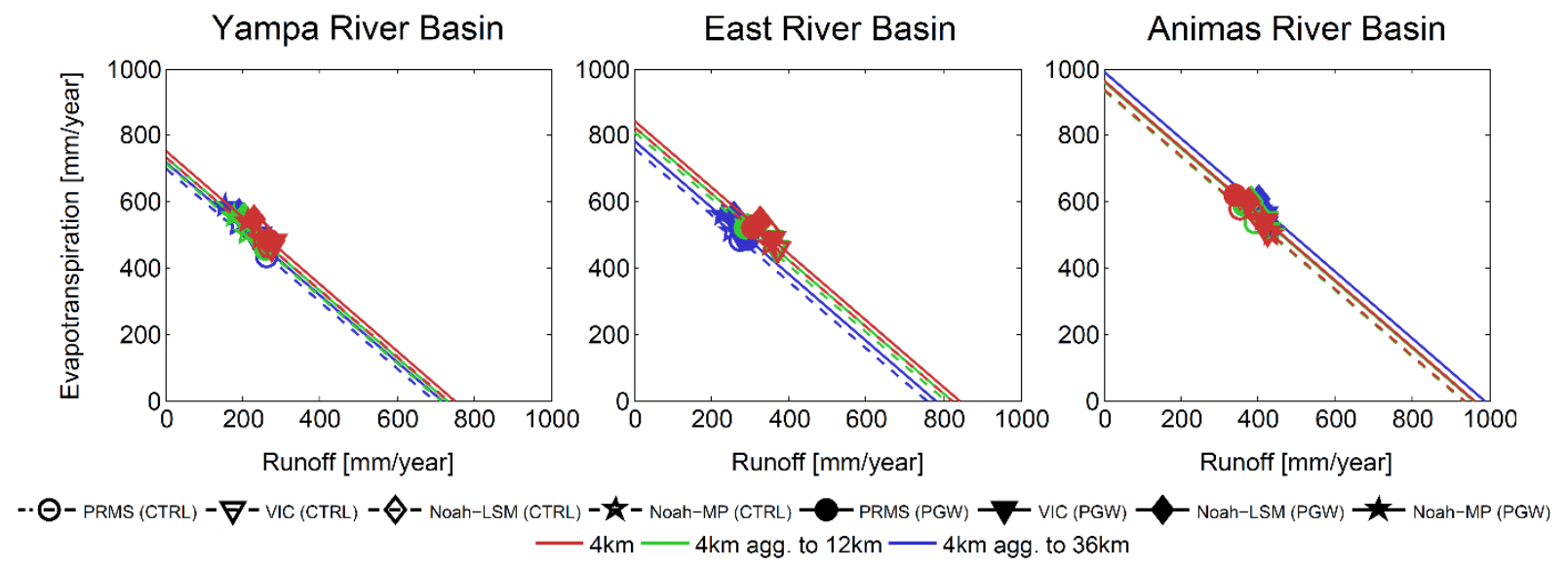

Figure 6: Partitioning of current (CTRL) and future (PGW) basin-averaged mean annual precipitation (diagonal, $\mathrm{mm} / \mathrm{year}$ ) into basin-averaged mean annual runoff (x axis, $\mathrm{mm} / \mathrm{year}$ ) and evapotranspiration (y axis, mm/year) obtained from various model structures (i.e. different symbols) and forcing datasets (i.e. different colors) for the period Oct/2002 - Sep/2008. Results are displayed for (a) experiment 1 (effects of WRF horizontal resolution) and (b) experiment 2 (effects of spatial forcing aggregation). 
(a) Experiment 1: effects of WRF horizontal resolution
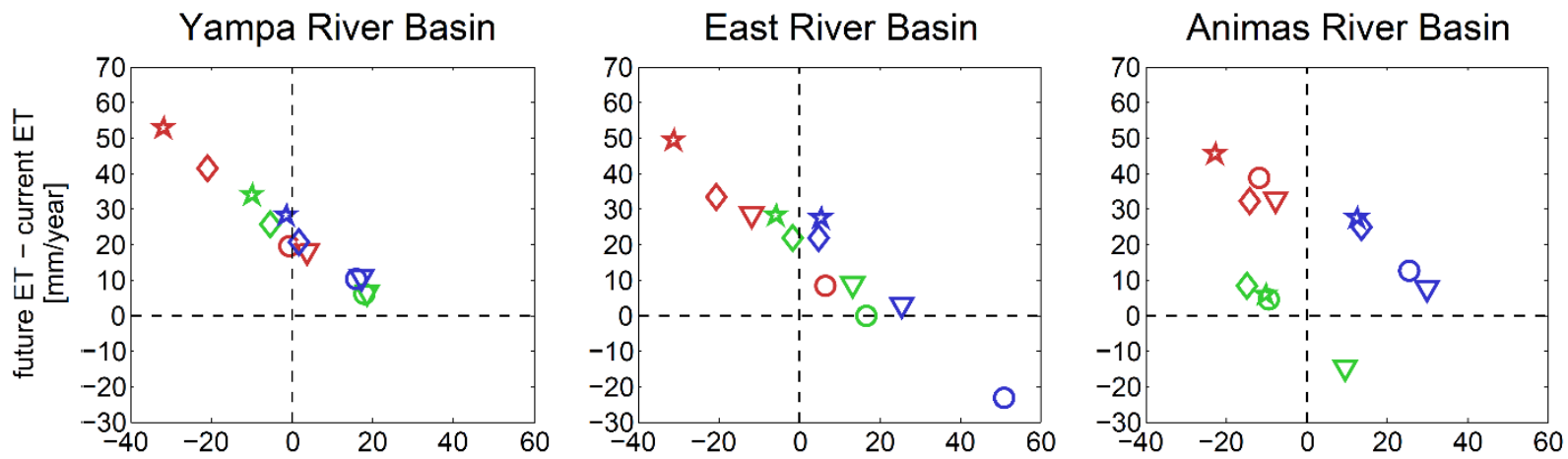

future runoff - current runoff [mm/year]

future runoff - current runoff [mm/year]

future runoff - current runoff [mm/year]

$O$ PRMS $\nabla$ VIC

$\diamond$ Noah-LSM $\star$ Noah-MP- $4 \mathrm{~km}-12 \mathrm{~km}-36 \mathrm{~km}$

(b) Experiment 2: effects of spatial aggregation
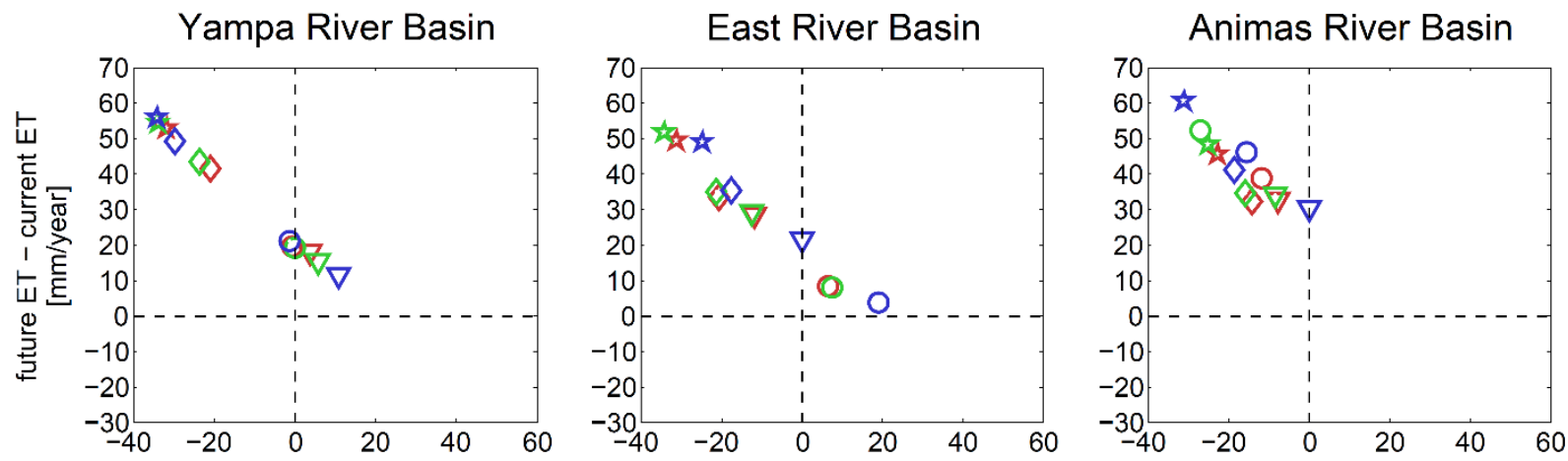

future runoff - current runoff [mm/year]

future runoff - current runoff [mm/year] future runoff - current runoff [mm/year]

$O$ PRMS $\nabla$ VIC $\diamond$ Noah-LSM $\star$ Noah-MP— $4 \mathrm{~km}-4 \mathrm{~km}$ agg. to $12 \mathrm{~km}-4 \mathrm{~km}$ agg. to $36 \mathrm{~km}$

Figure 7: Projected changes in basin-averaged mean annual runoff ( $\mathrm{x}$ axis, mm/year) and evapotranspiration (y axis, $\mathrm{mm} / \mathrm{year}$ ) obtained from various model structures (i.e. different symbols) and forcing datasets (i.e. different colors) for the period Oct/2002 - Sep/2008. Results are displayed for (a) experiment 1 (effects of WRF horizontal resolution) and (b) experiment 2 (effects of spatial forcing aggregation). 
(a) Experiment 1
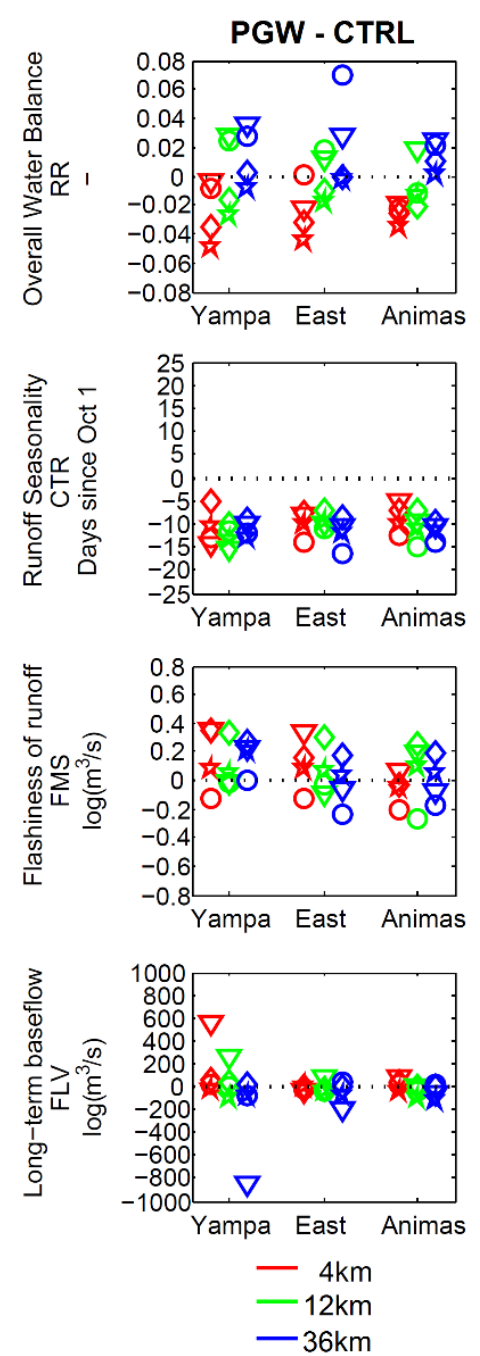

O PRMS $\nabla \mathrm{VIC}$ (b) Experiment 2

PGW - CTRL
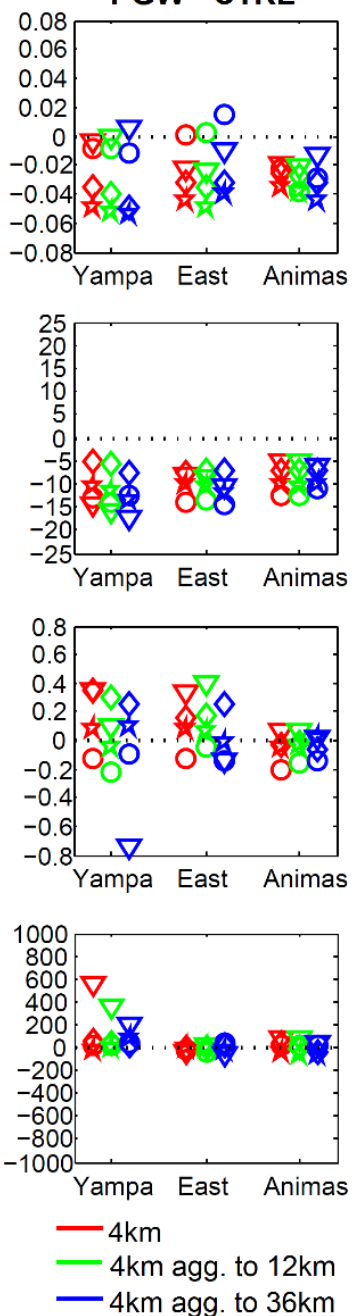

Figure 8: Difference between future (PGW) and current (CTRL) simulated signature measures of hydrologic behavior, obtained from various hydrologic model structures (i.e. different symbols) and forcing datasets (i.e. different colors) over a six-average water year (Oct/2002 - Sep/2008). Results are displayed for (a) experiment 1 (effects of WRF horizontal resolution) and (b) experiment 2 (effects of spatial forcing aggregation). 